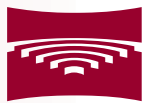
Rīgas StRadiña UNIVERSITĀTE

\title{
Vladislavs Ananjjevs
}

\section{Divfāžu kalcija fosfāta biokeramikas ietekme uz osteoporotisku kaulu biomehāniskiem rādītājiem un minerālblīvumu (eksperimentāls pētijjums)}

Promocijas darba kopsavilkums zinātniskā doktora grāda "zinātnes doktors (Ph.D.)" iegūšanai

Nozare - medicīniskā inženierija Apakšnozare - biomehānika 


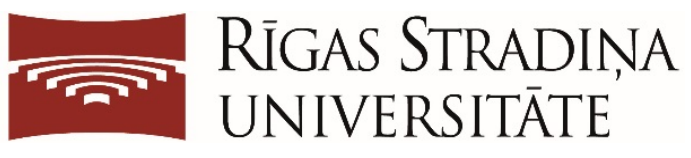

\author{
Vladislavs Ananjjevs \\ ORCID 0000-0002-0498-1403
}

Divfāžu kalcija fosfāta biokeramikas ietekme uz osteoporotisku kaulu biomehāniskiem rādītājiem un minerālblīvumu (eksperimentāls pētījums)

Promocijas darba kopsavilkums zinātniskā doktora grāda "zinātnes doktors (Ph.D.)" iegūšanai

Nozare - medicīniskā inženierija Apakšnozare - biomehānika Rīga, 2021 
Promocijas darbs izstrādāts Rīgas Stradiṇa universitātes Biomehānikas laboratorijā, Latvijā

Promocijas darba vadītāji:

Dr. habil. med. profesors Jānis Vētra,

Rīgas Stradina universitāte, Latvija

Dr. habil. sc. ing. profesors Vladimirs Kasjanovs,

Rīgas Stradina universitāte, Latvija

Zinātniskais konsultants:

Dr. med., Dr. habil. med. profesors Andrejs Skaǵers,

Rīgas Stradina universitāte, Latvija

Oficiālie recenzenti:

Dr. sc. ing. asociētā profesore Kristīne Šalma-Ancāne,

Rīgas Tehniskās universitates Rūdolfa Cimdina Rīgas biomateriālu inovācijas un attīstības centrs, Latvija

Dr. med. profesors Ilmārs Dūrītis,

Latvijas Lauksaimniecības universitāte

Dr. med. Simonas Grybauskas,

Viḷnas Universitāte, Lietuva

Promocijas darbs tiks aizstāvēts "Medicīnas bāzes zinātnes, tai skaitā farmācija" promocijas padomes atklātā sēdē 2021. gada 18. jūnijā plkst. 11.00, attālināti tiešsaites platformā Zoom.

Ar promocijas darbu var iepazīties RSU bibliotēkā un RSU tīmekḷa vietnē: https://www.rsu.lv/promocijas darbi

Promocijas padomes sekretārs:

Dr. biol. profesors Pēteris Tretjakovs 


\section{Saturs}

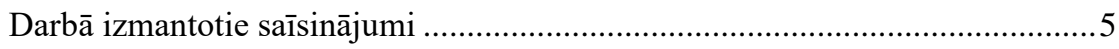

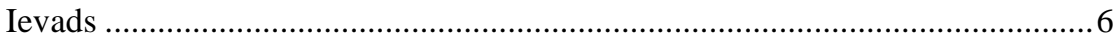

Darba aktualitāte ............................................................................6

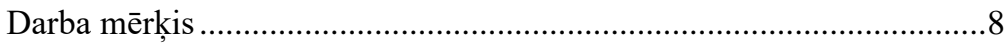

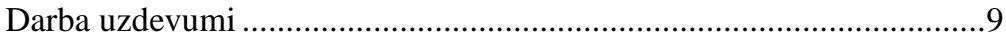

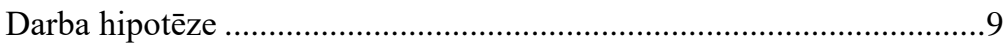

Pētījuma zinātniskā novitāte.............................................................

Pētījuma uzbūve (dizains) ................................................................. 10

Pētījuma izpild̄̄̌šanas vietas ..............................................................10

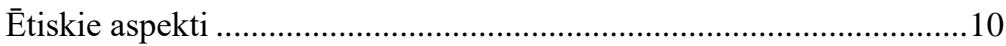

Darba struktūra un apjoms .............................................................. 11

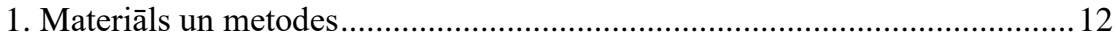

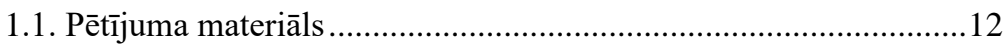

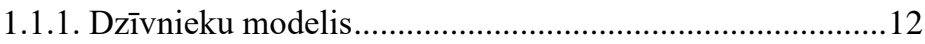

1.1.2. Biomateriālu sagatavošana ...............................................17

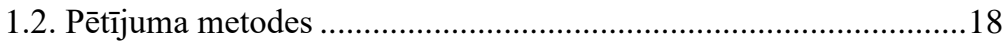

1.2.1. Biomehāniskā pētījuma metode .......................................18

1.2.2. Rentgenologiskā pētījuma metode ..................................25

1.2.3. Morfologiskā pētìjuma metode.........................................26

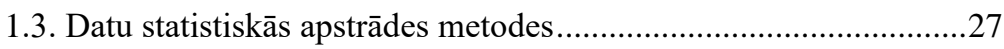

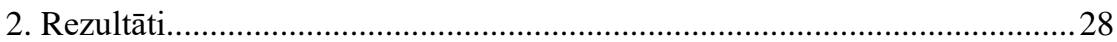

2.1. Biomehāniskā pētījuma un datu statistiskās apstrādes rezultāti

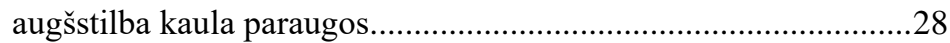

2.1.1. Graujošās deformācijas noteikšanas un datu statistiskās apstrādes rezultāti......................................................28

2.1.2. Graujošā sprieguma noteikšanas un datu statistiskās apstrādes rezultāti. 
2.1.3. Lieces moduḷa noteikšanas un datu statistiskās apstrādes rezultāti

2.2. Biomehāniskā pētījuma un datu statistiskās apstrādes rezultāti apakšžokḷa kaula paraugos

2.2.1. Graujošās deformācijas noteikšanas un datu statistiskās apstrādes rezultāti

2.2.2. Graujošā sprieguma noteikšanas un datu statistiskās apstrādes rezultāti.

2.2.3. Lieces moduḷa noteikšanas un datu statistiskās apstrādes rezultāti

2.3. Rentgenologiskā pētījuma un datu statistiskās apstrādes rezultāti augšstilba kaula paraugos.

2.4. Rentgenologiskā pētījuma un datu statistiskās apstrādes rezultāti apakšžokḷa kaula paraugos

2.5. Operēta un neoperēta augšstilba biomehānisko parametru un minerālblīvuma salīdzinājums pēc dažāda biomateriāla implantācijas

2.6. Morfologisiskā pētījuma un datu statistiskās apstrādes rezultāti apakšžokḷa kaula paraugos

3. Diskusija .44

Secinājumi 51

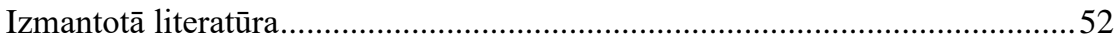

Autora publikācijas un tēzes par pētījuma tēmu .................................................56

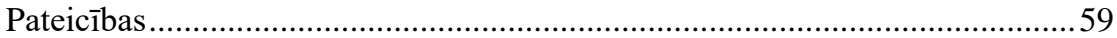




\section{Darbā izmantotie saīsinājumi}

\begin{tabular}{|l|l|l|}
\hline Abreviatūra & Nosaukums latviešu valodā & \multicolumn{1}{|c|}{ Nosaukums anglu valodā } \\
\hline GPa & Gigapaskāls & Gigapascal \\
\hline $\mathrm{HAP}$ & Hidroksiapatīts & Hydroyapatite \\
\hline $\mathrm{HU}$ & Haunsfīlda vienības & Hounsfield units \\
\hline LLU & $\begin{array}{l}\text { Latvijas Lauksaimniecības } \\
\text { universitāte }\end{array}$ & $\begin{array}{l}\text { Latvia University of Life } \\
\text { Sciences } \text { and Technologies }\end{array}$ \\
\hline $\mathrm{M}$ & Molmasa & Mole \\
\hline $\mathrm{MPa}$ & Megapaskāls & Megapascal \\
\hline $\mathrm{p}$ & Būtiskuma (nozīmības) līmenis & $\begin{array}{l}\text { The level } \text { of marginal } \\
\text { significance }\end{array}$ \\
\hline $\mathrm{Pa}$ & Paskāls & Pascal \\
\hline $\mathrm{RSU}$ & Rīgas Stradiña universitāte & Rīga Stradiňš University \\
\hline $\mathrm{SD}$ & Standarta deviācija & Standard deviation \\
\hline $\mathrm{TCP}$ & Trikalcija fosfāts & Tricalcium phosphate \\
\hline VPP & Valsts pētniecības programma & National research program \\
\hline
\end{tabular}




\section{Ievads}

\section{Darba aktualitāte}

Osteoporoze ir sistēmiska skeletālā slimība, kurai raksturīga samazināta kaulu masa un kaulaudu mikroarhitektūras izmaiņas, kā rezultātā palielinās kaulu trauslums (Blanchard et al., 2019). Palielinoties iedzīvotāju vecumam un dzīvildzei, osteoporoze kḷūst arvien plašāk izplatîta. Ar sabiedrības novecošanos osteoporoze arvien vairāk kḷūst par globālu problēmu. Pašlaik osteoporoze skar vairāk nekā 200 miljonus cilvēku visā pasaulē. Eiropas valstīs aptuveni $30 \%$ sieviešu, kas ir pēcmenopauzes periodā, tiek diagnosticēta osteoporoze (Sözen et al., 2017).

Osteoporozes profilakse ir kritienu nepiel̦aušana, redzes un dzirdes traucējumu novēršana, fiziskās aktivitātes, smēķēšanas un alkohola lietošanas pārtraukšana, kā arī atbilstoša D vitamīna, olbaltumvielu un kalcija uzṇemšana (Föger-Samwald et al., 2020). Osteoporozes medikamentozā ārstēšanā parasti tiek izmantoti perorālie bifosfonāti (alendronāts, risedronāts un ibandronāts). Sievietēm, kurām ir perorālu bifosfonātu grupas medikamentu nepanesība (vai tie ir kontrindicēti), intravenoza bifosfonātu vai denosumaba lietošana ir vislabākā alternatīva (Kanis et al., 2019). Aptuveni viena no trīs sievietēm un viens no pieciem vīriešiem pēc 50 gadu vecuma piedzīvo osteoporotiskus lūzumus. Osteoporozes izraisīti lūzumi palielina saslimstību un pāragru mirstību, it sevišḳi gados vecākiem cilvēkiem (Sözen et al., 2017). Osteoporotisko lūzumu ārstēšana viniiem ir problemātiska, jo ir mazākas lūzumu dzišanas spējas, kas korelē ar daudz augstāku implanta fiksācijas neveiksmju līmeni salīdzinājumā ar jaunākiem pacientiem. Bieži tiek veiktas ķirurğiskas procedūras, lai salabotu bojāto kaulu, izmantojot skrūves vai fiksācijas plāksnes. Sakarā ar augsto porainību un zemo osteoporotisko kaulaudu izturību, lai uzlabotu iznākumu, 
implantus bieži papildina ar dažādiem kaula biomateriāliem (Offermanns et al., 2018).

Divdesmit pirmā gadsimta sākumā strauji sākās plaša biomateriālu izmantošana ortopēdijas praksē. Pēdējā desmitgadē vairākos veselības jomu segmentos tiek meklēti bioloǵiski saderīgi materiāli defektīvu kaulu rekonstrukcijai (Ratner et al., 2013). Kaulaudu aizvietojošo biomateriālu izmantošanas iespēju pētniecība ir aktuāla arī Latvijā. Biomateriālam jābūt saderīgam ar implantācijas vietu, netoksiskam, nekancerogēnam, ḳīmiski un biologiski stabilam, ar atbilstošu blīvumu, svaru, mehānisko izturību un elastību. Autogēnie kaula transplantāti, kas satur minerālo komponentu un daudz imūnkompetento šūnu osteoǵenēzei, ir labākais kaulaudu aizvietošanas materiāls, tomēr ir vajadzịgas divas ķirurğiskas vietas un kaula avots ir ierobežots (Leite et al., 2008).

Kaula reǵenerācija ir kaulaudu veidošanās fizioloǵiskais process, kas notiek normāla lūzuma sadzīšanas laikā un ir iesaistīts nepārtrauktā kaula aprites procesā dzīves laikā. Tomēr ir dažādi klīniski apstākḷi, kad nepieciešama plaša kaula reǵenerācija, piemēram, osteoporotisko kaulu lūzumu gadījumā (Dimitriou et al., 2011). Biokeramikas materiāliem ir milzīgs potenciāls dabisko kaulu audu atjaunošanai (Wang et al., 2017). Kalcija fosfātu saturošs biomateriāls hidroksiapatīts (HAP), kas var būt gan tīrā veidā, gan pārklāts ar medikamentiem, ir viens no zināmākajiem un klīniski izpētītiem kaulaudu atjaunošanas līdzekḷiem. Kalcija fosfāts stimulē kaulu dzī̌anu osteovadītspējas, bioloǵiskās saderības un bionoārdīšanās īpašības dēl (Schlickewei et al., 2015). Divfāžu kalcija fosfāta biokeramika kā kaulu aizstājējmateriāls tiek izmantots, lai uzlabotu osteoporotisko kaulu īpašības un veicinātu kaulaudu dzīšanu. Kalcija hidroksiapatîts (HAP) ir l̦oti bioakumulatīvs un veido tiešu saikni ar kaulaudiem. Trikalcija fosfāts (TCP) darbojas kā katalizators jaunu kaulaudu veidošanās stimulěšanai (Ratner et al., 2013). Stronciju saturošie kalcija fosfāta kaulaudu 
cementi ir perspektīvi materiāli ar osteoporozi saistītu defektīvu kaulu reǵenerācijai, jo tie stimulē kaulu veidošanos un vienlaikus ierobežo osteoklastu darbību (Lode et al., 2017).

Rīgas Tehniskās universitātes Rūdolfa Cimdiṇa Rīgas biomateriālu inovāciju un attīstības centrā tiek veikta kaulaudu aizvietojošu materiālu izpēte. Šim centram ir vairāk nekā 20 gadu pieredze sadarbībā ar Rīgas Stradiṇa universitātes Mutes, sejas un žokḷu ķirurǵijas katedru jaunu sintētisko biomateriālu eksperimentālajā un klīniskajā aprobācijā. Darbs norisinās pie hidroksiapatīta, divfāžu kalcija fosfăta cementa, polimetilmetakrilāta cementa, stikla-jonomēra cementa sintezēšanas un to īpašību pētniecības. No minētajiem materiāliem promocijas darba autora eksperimentālajā pētījumā ar dzīvniekiem tika izmantoti divfāžu kalcija fosfāta biokeramikas materiāli.

Jebkurš biomateriāls, kurš tiek implantēts dzīvā organismā, izraisa noteiktu lokālu reakciju. Reakcija ir atkarīga no materiāla fizikālajām un ķīmiskajām īpašībām. Tika izstrādāta reaktogenitātes teorija, dalot audu reakciju uz implantāciju nespecifiskā un specifiskā reakcijā, kas kopā veido biosaderību (Slutskii et Vetra, 1996). Literatūrā ir maz datu par organisma vispārējo reakciju uz biomateriālu implantāciju. Joprojām nav noskaidrots, kādas ir kaulaudu īpašību izmaiņas blakus implantācijas zonai un attālinātos rajonos pēc biomateriālu implantācijas.

\section{Darba mērḳis}

Pētījuma mērķis ir noteikt kaulaudu minerālblīvuma, biomehānisko un morfologiisko īpašību izmaiņas pēc lokālas augšstilba kaula trochanter major apvidus pastiprināšanas ar divfāžu kalcija fosfâta biokeramiskajiem materiāliem trušiem ar eksperimentālu osteoporozi. 


\section{Darba uzdevumi}

1. Noteikt operēta, neoperēta augšstilba un apakšžokḷa kaula paraugu graujošo deformāciju dažādām eksperimentālo dzīvnieku grupām.

2. Noteikt operēta, neoperēta augšstilba un apakšžokḷa kaula paraugu graujošo spriegumu dažādām eksperimentālo dzīvnieku grupām.

3. Noteikt operēta, neoperēta augšstilba un apakšžokḷa kaula paraugu lieces moduli dažādām eksperimentālo dzīvnieku grupām.

4. Noteikt operēta, neoperēta augšstilba un apakšžokḷa kaula paraugu minerālblīvumu dažādām eksperimentālo dzīvnieku grupām.

5. Salīdzināt eksperimentālo dzīvnieku operēta un neoperēta augšstilba kaula paraugu biomehāniskus rādītājus un minerālblīvumu pēc dažāda veida biomateriālu implantācijas.

6. Statistiski salīdzināt iegūtos rezultātus starp dažādām eksperimentālo dzīvnieku grupām pēc biomateriālu implantācijas ar vai bez stroncija.

7. Noteikt apakšžokḷa kaula paraugu šķērsgriezumā trabekulāra kaula laukumu pēc dažādu veidu biomateriālu implantācijas eksperimentālajiem dzīvniekiem un kontroles grupai.

\section{Darba hipotēze}

Lokāla pastiprināšana ar divfāžu kalcija fosfăta biokeramiskajiem materiāliem augšstilba trochanter major apvidū dzīvniekiem ar eksperimentālu osteoporozi uzlabo kaulaudu biomehānikās īpašības un palielina minerālblīvumu.

\section{Pētījuma novitāte}

Tika pierādīts, ka Rīgas Tehniskās universitātes Rūdolfa Cimdiṇa Rīgas biomateriālu inovāciju un attīstības centra divfāžu kalcija fosfāta biokeramikas materiāli, kuri tiek izmantoti RSU Stomatologijas institūtā defektīvu kaulu 
aizvietošanai, pēc implantācijas osteoporotiskā kaulā ievērojami palielina tā minerāblīvumu un uzlabo biomehāniskās īpašības.

\section{Pētījuma uzbūve (dizains)}

Eksperimentāls salīdzinošs pētījums ar placebo ķirurğijas un kontroles grupu.

Pētījuma grupas: sieviešu dzimtes truši ar eksperimentāli izraisītu osteoporozi, kam augšstilba lielā grozītāja rajonā ievietotas divfāžu kalcija granulas ar un bez stroncija.

Placebo ķirurğijas grupa: dzīvnieki ar eksperimentāli izraisītu osteoporozi bez biomateriāla granulu ievietošanas kaulā.

Kontroles grupa: veseli dzīvnieki.

\section{Pētījuma izpildīšanas vietas}

Rīgas Stradiṇa universitātes Biomehānikas laboratorija - kaulu paraugu biomehānisko īpašību noteikšana.

Rīgas Stradiņa universitāte, Stomatolog̣ijas institūts - kaulu paraugu minerālblīvuma noteikšana ar datortomogrāfijas palīdzību.

Rīgas Stradiṇa universitātes Patologiijas katedra - kaulu paraugu morfolog̣iskā analīze.

“Liepadent” zobārstniecības klīnikas zobu tehniskā laboratorija - kaulu paraugu sagatavošana biomehānisko īpašību izpētei.

\section{Ẽtiskie aspekti}

Pētījums ir veikts, ievērojot ētikas normas, kas ir noteiktas eksperimentālo pētījumu veikšanai. Pētījumam ir izsniegta Latvijas Pārtikas un veterinārā dienesta aţ̣auja un Rīgas Stradiṇa universitātes Ētikas komitejas ațauja. 


\section{Darba struktūra un apjoms}

Promocijas darbs uzrakstîts latviešu valodā. Tam ir klasiska struktūra un 10 daḷas: ievads, literatūras apskats, materiāls un metodes, rezultāti, diskusija, secinājumi, izmantotās literatūras saraksts, autora publikācijas un tēzes par pētījuma tēmu, pateicības un pielikumi. Promocijas darba apjoms: 106 lappuses, tajā skaitā 45 attēli un 1 tabula. Izmantotās literatūras sarakstā minēti 174 zinātnisku rakstu un 6 grāmatu avoti. 


\section{Materiāls un metodes}

\subsection{Pētījuma materiāls}

\subsubsection{Dzīvnieku modelis}

Pētījumā tika izmantoti 34 astoṇus mēnešus veci sieviešu dzimtes eksperimenta dzīvnieki - "Kalifornijas" un "Lielais marders" šḳirnes truši no trušu audzētavas "Podziņas”, Ādažu novads, Latvija, LV-2164, novietnes Nr. 1382580, ganāmpulka Nr. LV06178330 (RSU Iepirkuma komisijas lēmums Nr. 5-2/80 (17.02.2015.)) ar vidējo svaru pirms eksperimenta 3,87 kg (2,9-5,0).

Dzīvnieki tika turēti Rīgas Stradiṇa universitātes Eksperimenta dzīvnieku audzētavā (faktiskā adrese: Kristapa Helmaņa iela 8, Jelgava, LV-3004). Stacionārs $\left(32,8 \mathrm{~m}^{2}\right)$ un ķirurgijas zāle $\left(62,0 \mathrm{~m}^{2}\right)$ tika nomāti no Latvijas Lauksaimniecības universitātes uz līguma Nr. 4.4.-9/15/2015 pamata. Pētījuma laikā tika ievērotas prasības saskaņā ar Ministru kabineta noteikumiem Nr. 52 "Noteikumi par zinātniskiem mērķiem izmantojamo dzīvnieku aizsardzību". Dz̄ivnieki tika izmitināti pa vienam $100 \times 45 \times 62 \mathrm{~cm}$ izmēra būros. To barībai izmantoja pḷavas sienu un auzas, savukārt dzirdināšanai - krāna ūdeni. Eksperimenta laikā visiem trušiem tika aț̣autas brīvprātīgas kustības, bija pieejams ēdiens un ūdens jebkurā brīdī.

Eksperimentāla osteoporoze tika izraisīta 24 trušiem pēc ovariektomijas un sekojošas metilprednizolona injekcijas. Viens trusis exitus letalis 28. dienā pēc metilprednizolona kursa uzsākšanas laika. Kontroles grupā bija 10 veseli truši. Biomateriālu implantācijas operācijas un dzīvnieku eitanāzija tika veikta laika posmā no 2016. gada 20. februāra līdz 2016. gada 13. maijam. 


\section{Eksperimentālās osteoporozes ierosināšanas protokols}

Eksperimentālā osteoporoze tika ierosināta uz iepriekš zinātniskajā literatūrā aprakstîtās metodologijas principiem (Baofeng et al., 2010; Wanderman et al., 2018). Ķirurğiskās manipulācijas tika veiktas vispārējā anestēzijā, izmantojot ketamīna $10 \%$ šḳīdumu devā $30 \mathrm{mg} / \mathrm{kg}$ ķermeņa svara, ksilazīna 2 \% šḳīdumu devā $3 \mathrm{mg} / \mathrm{kg}$ ķermeņa svara, atropīna 0,1 \% šḳīdumu devā $0,1-0,5 \mathrm{mg} / \mathrm{kg}$ ķermeņa svara. Ķirurğijas pirmajā posmā pēc operācijas lauka sagatavošanas tika veikts $3 \mathrm{~cm}$ grieziens vēdera priekšèjā sienā pie nabas pa viduslīniju (operēja prof. A. Skaǵers, asoc. prof. G̣. Šalms). Tika atvērts vēdera dobums, atrastas un pēc liğěšanas pie pamatnes nogrieztas olnīcas, pārbaudīta hemostāze (1.1. att.).

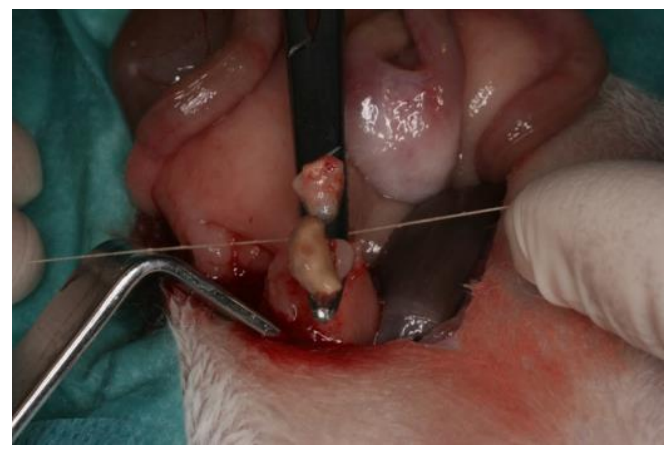

\section{1. att. Abpusējās ovariektomijas operācija}

(fotogrāfija no doc. I. Šalmas personīgā arhīva)

Vēdera siena tika slēgta divās kārtās ar resorbējošiem 4/0 diegiem. Āda tika slēgta bez iesprieguma ar neresorbējošiem 4/0 diegiem, kuri tika noṇemti desmitajā pēcoperācijas dienā. Sāpes pēcoperācijas periodā tika kontrolētas, subkutāni injicējot ketoprofēnu $1-3 \mathrm{mg} / \mathrm{kg}$ vienu reizi dienā trīs pirmās dienas.

Kad brūce bija sadzijusi un dzīvnieka veselības stāvoklis normalizējies, pēc 14 dienām tika uzsākts 6 nedēḷu metilprednizolona kurss intramuskulāri $1 \mathrm{mg} / \mathrm{kg}$ dienā. Metilprednizolona kursa laikā dzīvnieki saṇēma 
hepatoprotektoru Hepatiale Forte $170 \mathrm{mg}$ dienā (fosfolipīdi $85 \mathrm{mg}$, L-ornitīna L-aspartāts 85 mg).

Medikamentu izvēle un devas balstītas uz LLU Veterinārmedicīnas Preklīniskā institūta asociētās profesores Aijas Ilgažas ieteikumiem un datiem no James W. Carpenter “Exotic Animal Formulary” un Ian Ramsey “BSAVA Small Animal Formulary”. Veterināro medikamentu izmantošanu trušiem veica veterinārārste Jekaterina Peț̣a, kura arī uzṇēmās nodrošināt eksperimenta dzīvnieku labturīgu aprūpi pēcoperācijas periodā.

\section{Kaula defekta veidošana placebo paraugiem un ar biomateriālu implantāciju}

Ķirurǵijas otrajā posmā labā augšstilba trochanter major rajonā vispārējā anestēzijā tika veikts aptuveni $2 \mathrm{~cm}$ garš grieziens, atslāṇoti mīkstie audi un periosts (1.2. att.).

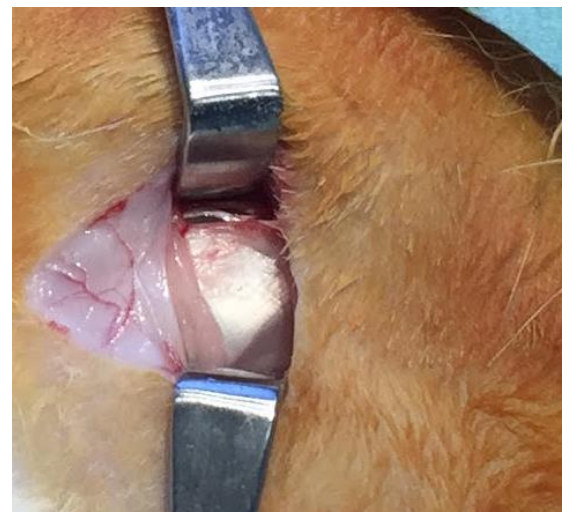

\section{2. att. Labā augšstilba trochanter major rajons}

(fotogrāfija no doc. I. Šalmas person̄̄gā arhīva)

Ar trepāna urbi $5 \mathrm{~mm}$ diametrā un $4 \mathrm{~mm}$ dziḷumā tika izveidots apaḷs defekts augšstilba lielā grozītāja rajonā (1.3. att.). 


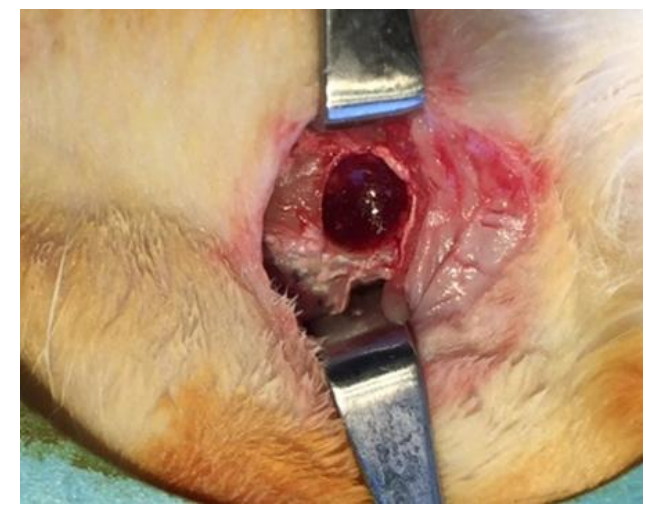

\section{3. att. Kaula defekts $5 \times \mathbf{4} \mathbf{~ m m}$ apjomā augšstilba lielā grozītāja rajonā}

(fotogrāfija no doc. I. Šalmas personīgā arhīva)

23 eksperimentālie dz̄̄vnieki tika iedalīti trīs grupās: 1. grupa ( 8 truši) defekti tika aizpildīti ar HAP/TCP (70/30) granulām, 2. grupa (8 truši) - defekti tika aizpildīti ar HAP/TCP (70/30) granulām, kam pievienoti $5 \%$ stroncija, 3. placebo ķirurgijas grupa ( 7 truši) - defekti tika radīti, bet materiāls netika ielikts (1.4. att.).

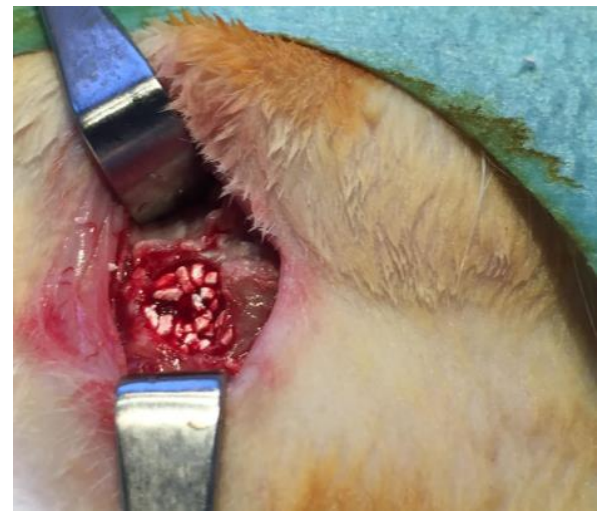

1.4. att. Biomateriāla implantācija augšstilba trochanter major rajonā

(fotogrāfija no doc. I. Šalmas personīgā arhīva) 
Virs kaula defekta periosts tika slēgts ar uzsūcošiem 4/0 diegiem; āda slēgta bez iesprieguma ar neresorbējošiem 4/0 diegiem, kuri tika noṇemti desmitajā pēcoperācijas dienā (1.5. att.).

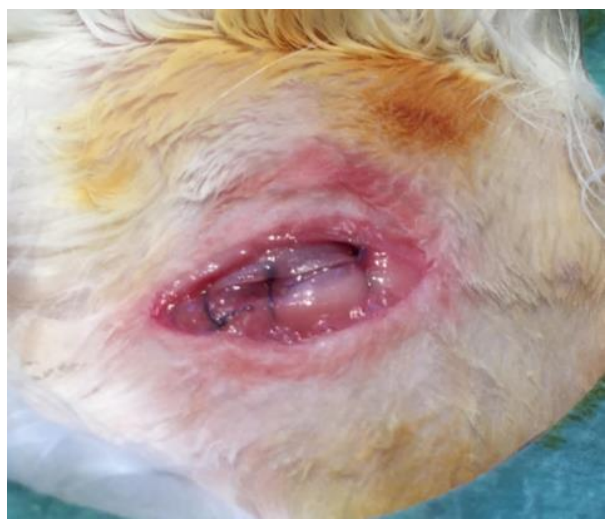

\section{5. att. Periosta slēgšana ar uzsūcošiem diegiem}

(fotogrāifija no doc. I. Šalmas personīgā arhīva)

Dzīvniekiem tika veikta novērošana, novērtējot ūdens un ēdiena patēriṇu, svara izmaiṇas, šuvju, brūču stāvokli, dzīvnieku uzvedību, ārējo izskatu. Eksperimenta laikā netika novērotas fiziskās aktivitātes vai apetītes zudums.

\section{Dzīvnieku eitanāzija un kaulu paraugu ņemšana}

Dzīvnieku eitanāzija tika veikta trīs mēnešus pēc kaula defekta veidošanas vispārējā anestēzijā, ievadot preparātu T-61 intrapulmonāli, deva $1,0 \mathrm{ml} / \mathrm{kg}$ ḳermeṇa svara. Lai iegūtu statistiski ticamus rezultātus, minimālais paraugu skaits bija vairāk nekā 6 (Yamada, 1970; Evans, 1971; Charan et al., 2013).

Osteoporozes pierādīšanai ar morfoloǵiskā pētījuma metodi tika ņemti 10 apakšžokḷa kaula premolāra rajona paraugi no veseliem trušiem un 23 apakšžokḷa kaula premolāra rajona paraugi no trušiem ar eksperimentālo osteoporozi. Lai 
noteiktu biomateriālu lokālo ietekmi, tika izmantoti 23 labā (operētā) augšstilba kaula paraugi no trušiem ar eksperimentālo osteoporozi, kā arī 23 kreisā (neoperētā) augšstilba un 23 apakšžokḷa kaula leṇķa rajona paraugi no trušiem ar eksperimentālo osteoporozi, lai noteiktu sistēmisku biomateriāla iedarbību ar biomehāniskā un rentgenologiskā pētījuma metodēm (1.6. att.).

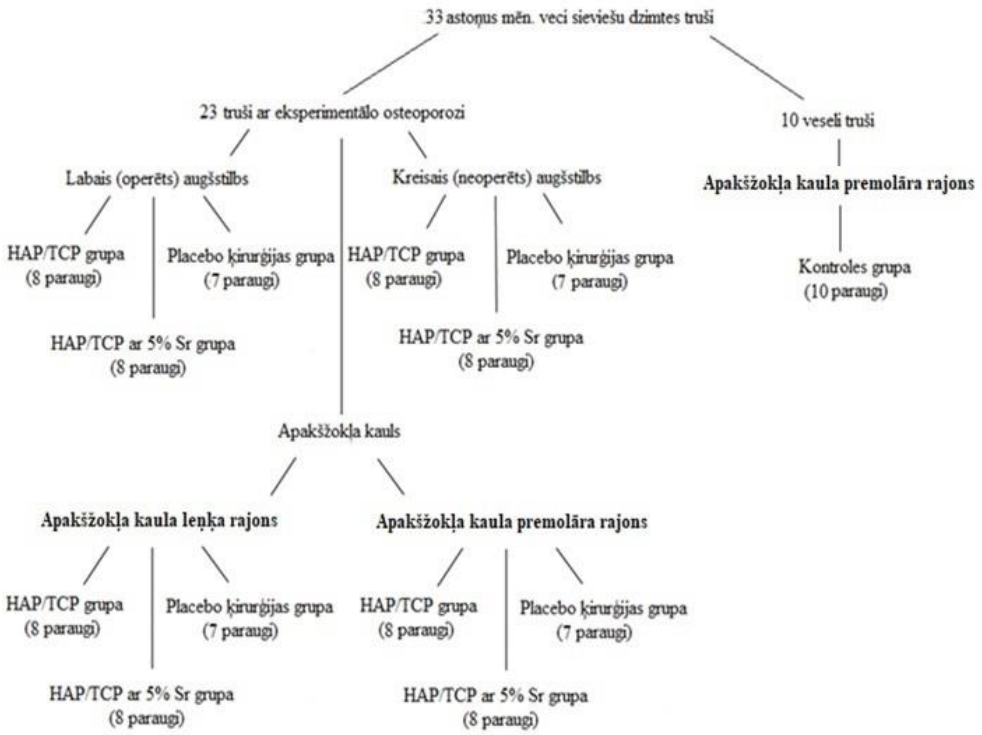

\section{6. att. Trušu kaulu paraugu sadalījuma shēma}

\subsubsection{Biomateriālu sagatavošana}

Pētījumam tika izmantoti nekomerciālie Rīgas Tehniskās universitātes Rūdolfa Cimdiṇa Rịgas biomateriālu inovāciju un attīstības centrā ražoti biomateriāli. Kalcija fosfăta materiālu sintēze un granulu izgatavošana tika realizēta, kā iepriekš aprakstīts zinātniskajā literatūrā (Grybauskas et al., 2016; Zarins et al., 2017). Pirms kalcija fosfātu sintēzes CaO (Fluka) un SrO (SigmaAldrich) aktivēšanas nolūkos tiek termiski apstrādāts augsttemperatūras krāsnī $1100{ }^{\circ} \mathrm{C}$ temperatūrā vienu stundu. No iegūtā kalcija oksīda un stroncija oksīda 
tika pagatavota $0,3 \mathrm{M} \mathrm{Ca}(\mathrm{OH})_{2}$ vai $\mathrm{Sr}(\mathrm{OH})_{2} / \mathrm{Ca}(\mathrm{OH})_{2}$ suspesija dejonizētā ūdenī. Kalcija fosfātu sintēze tika veikta reaktorā, hidroksīdu suspensijām to maisī̌sanas laikā pievienojot $2 \mathrm{M} \mathrm{H}_{3} \mathrm{PO}_{4}$ tādā daudzumā, lai iegūstamā produkta HAP/TCP fãžu attiecība pēc augsttemperatūras apstrādes būtu 70/30. Pēc sintēzes nogulsnes tika filtrētas un granulētas, izmantojot manuālu ekstrūzijas paņēmienu. Iegūtās granulas tika žāvētas un apdedzinātas $1150{ }^{\circ} \mathrm{C}$ temperatūrā divas stundas. Termiski apstrādātās granulas tika sadalītas pa frakcijām, tās sijājot ar vibrējošo sietu iekārtu, izmantojot sietus ar $1000 \mathrm{mkm}$ un $500 \mathrm{mkm}$ acu izmēru, tādējādi iegūstot nepieciešamo granulu frakciju (no $0,5 \mathrm{līdz} 1 \mathrm{~mm}$ ). Pēc sijāšanas granulas vairākkārt tika skalotas etanolā, lai atdalītu smalkākās daḷiṇas, un žāvētas $+70{ }^{\circ} \mathrm{C}$ temperatūrā.

Eksperimenta pētījumam in vivo biomateriāls pēc izgatavošanas tika testēts ar fizikāli ķīmiskām un šūnu kultūrās in vitro, atlasot maztoksiskākās, biosaderīgākās un osteogēnas bioaktivitātes ziṇā efektīvākās dalinnas.

Biomateriālu granulu raksturojošie parametri atrodami 1.1. tabulā.

1.1. tabula.

Biomateriālu granulu raksturojošie parametri.

\begin{tabular}{|c|c|c|c|c|}
\hline Biomateriāls & $\begin{array}{c}\text { Virsmas } \\
\text { laukums, } \mathrm{m}^{2} / \mathrm{g}\end{array}$ & $\begin{array}{c}\text { Tilpuma } \\
\text { blīvums, } \\
\mathrm{g} / \mathrm{cm}^{3}\end{array}$ & $\begin{array}{c}\text { HAP/TCP } \\
\text { saturs, } \\
\%\end{array}$ & $\begin{array}{c}\text { Sr saturs, } \\
\%\end{array}$ \\
\hline $\begin{array}{c}\mathrm{HAP} / \mathrm{TCP} \\
(70 / 30)\end{array}$ & $1.262 \pm 0.014$ & $0.98 \pm 0.01$ & $73 / 27$ & $0.017 \pm 0.002$ \\
\hline $\begin{array}{c}\mathrm{HAP} / \mathrm{TCP} \\
\text { ar Sr (70/30) }\end{array}$ & $1.124 \pm 0.0147$ & $1.05 \pm 0.02$ & $71 / 29$ & $6.7 \pm 0.7$ \\
\hline
\end{tabular}

Apzīmējums: HAP - hidroksilapatīts, TCP - trikalcija fosfāts, $\mathrm{Sr}$ - stroncijs

\subsection{Pētījuma metodes}

\subsubsection{Biomehāniskā pētījuma metode}


Pētījumā kaulaudu biomehānisku parametru noteikšanai tika veikts trīs punktu lieces izpētes tests (Prodinger et al., 2018), (1.7. att.).

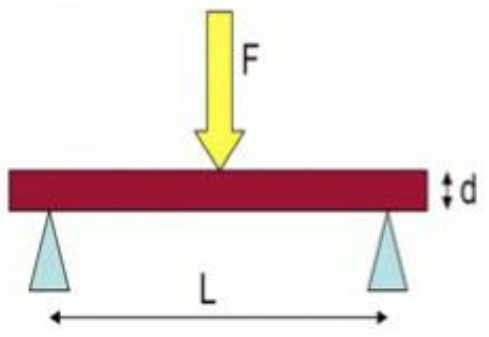

\section{7. att. Parauga trīs punktu lieces izpētes testa shēma:}

F - slogojums, L - laidums, d - parauga biezums

Lieces laikā katram paraugam tika noteikts graujošais (maksimālais) spriegums $\left(\sigma^{*}\right)$ un graujošā (maksimālā) deformācija $\left(\varepsilon^{*}\right)$. Datorprogramma mērījumu rezultātus atspoguḷoja tabulas veidā un grafiski kā spriegumadeformācijas līkni. Paraugu cietība tika izteikta kā pieskares lieces modulis uz noteiktas sprieguma-deformācijas līknes lineārās daḷas kā tangensa leṇkiis $\alpha$ $(\operatorname{tg} \alpha)$, kurš veidojas starp koordinātu asi un pieskares līkni tās lineārajā daḷā (1.8. att.).

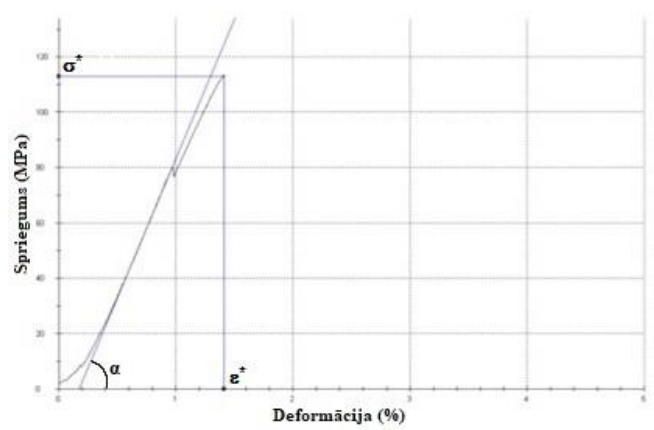

1.8. att. Tipiskā eksperimentālā sprieguma-deformācijas sakarība un galvenie nosakāmie mehāniskie parametri: $\sigma^{*}$ graujošais spriegums, $\varepsilon^{*}-$ graujošā deformācija, tg $\alpha$ - lieces modulis 
Graujošais spriegums tika aprēḳināts pēc formulas:

$$
\sigma=3 \mathrm{FL} /\left(2 \mathrm{bd}^{2}\right) \text {, }
$$

kur $\mathrm{F}$ - slogojums, $\mathrm{L}$ - laidums, $\mathrm{b}$ - parauga platums, $\mathrm{d}$ - parauga biezums.

Graujošais spriegums tika mērīts paskālos $(\mathrm{Pa})$.

Graujoša deformācija tika aprēḳināta pēc formulas:

$$
\varepsilon=6 \mathrm{df} / \mathrm{L}^{2},
$$

kur $\mathrm{d}$ - parauga biezums, $\mathrm{f}$ - parauga noliece un $\mathrm{L}$ - laidums.

Graujošā deformācija tika noteikta procentos (\%).

Liecies modulis tika aprēķināts pēc formulas:

$$
\mathrm{E}=\mathrm{FL}^{3} /\left(4 \mathrm{fbd}^{3}\right),
$$

kur F - slogojums, L - laidums, $\mathrm{f}$ - parauga noliece, $\mathrm{b}$ - parauga platums, $\mathrm{d}$ - parauga biezums.

Lieces modulis tika mērīts paskālos $(\mathrm{Pa})$.

Lieces modulis tika aprēḳināts sprieguma-deformācijas līknes lineārajā dạ̣ā relatīvā parauga deformācijas laikā $(\varepsilon=0,5 \%)$.

Kaulaudu biomehānisko īpašību izpētei par trīs punktu lieci tika izmantoti taisnstūra formas paraugi. Pielietojot fiziodispenseri Surgic Pro (NSK, Japāna), taisno galu un dimanta diska urbi ar diametru $5 \mathrm{~mm}$, tika izveidoti taisnstūra formas kaulaudu bloki (1.9. att.). 


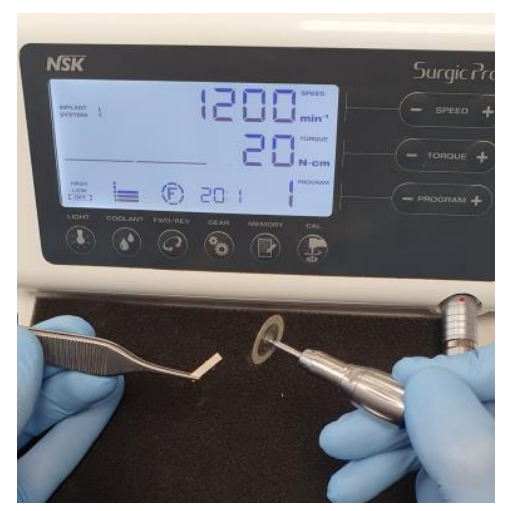

\section{9. att. Surgic pro fiziodispansers taisnstūra formas kaulu paraugu iegūšanai}

(fotogrāfija no darba autora personīgā arhīva)

Taisnstūra formas kaula paraugi tika iegūti no operēta augšstilba kaula diafīzes daḷas, neoperēta augšstilba kaula diafìzes daḷas un apakšžokḷa kaula leņ̧⿻a rajona (1.10. att.).
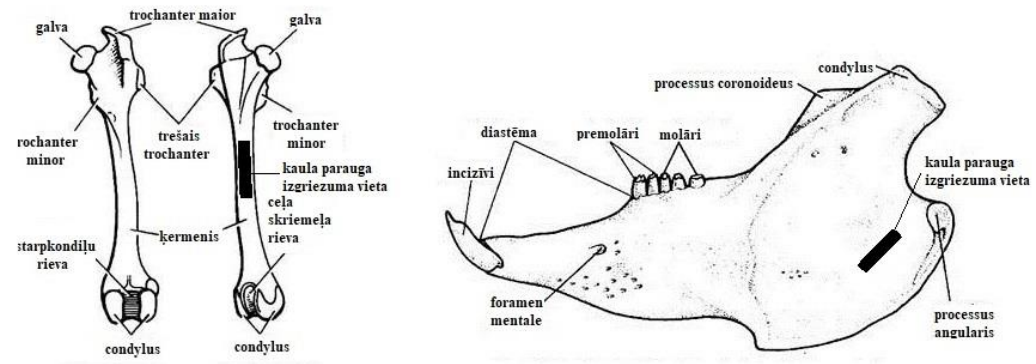

1.10. att. Shematisks trušu augšstilba un apakšžokḷa kaula zīmējums ar melno taisnstūri apzīmēta kaula paraugu izgriezuma vieta

(Endoskeleton of Rabbit (With Diagram)

NotesOnZoology.com, Fig. 29.11 un 29.19.

(http://www.notesonzoology.com/rabbit/endoskeleton/endoskeleton-of-rabbit-withdiagram-vertebrates-chordata-zoology/7690)) 
Visi paraugi tika pielīdzināti vienam lielumam, izmantojot speciāli izgatavotu ierīci paraugu kalibrēšanai un abrazīvo slīpēšanas disku: augšstilba kaula paraugu platums $3,2 \pm 0,02 \mathrm{~mm}$, biezums $0,61 \pm 0,02 \mathrm{~mm}$; apakšžokḷa kaula paraugu platums $3,2 \pm 0,02 \mathrm{~mm}, 0,32 \pm 0,02 \mathrm{~mm}$ biezums. Speciāla ierīce paraugu kalibrēšanai tika izgatavota un kalibrēta "Liepadent" zobu tehniskajā laboratorijā. Paraugi, kuri neatbilda noteiktiem izmēriem, netika izmantoti pētījumā (1.11. att.).

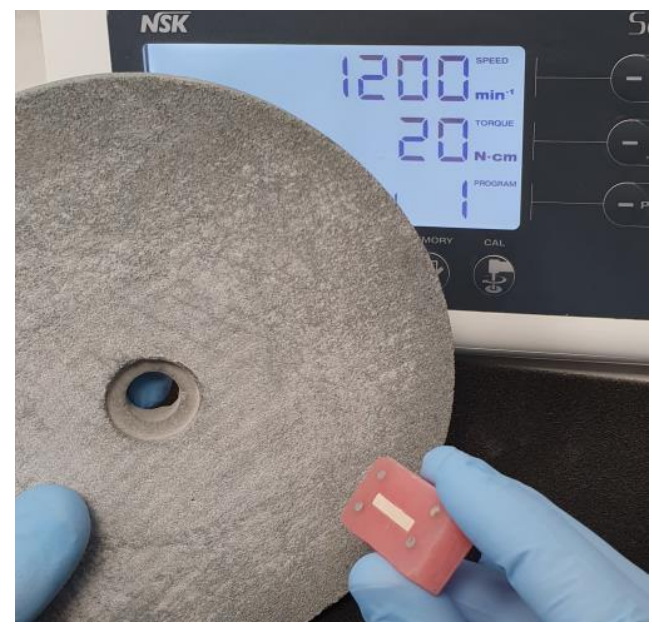

1.11. att. Speciāli izgatavota ierīce paraugu kalibrēšanai un abrazīvais slīpēšanas disks kaulu paraugu pielīdzināšanai

(fotogrāfija no darba autora personīgā arhīva)

Kaulu paraugu platums un biezums tika izmērīts ar katetometru KM-6 (Lomo, Krievija), mērījuma precizitāte $\pm 0,01 \mathrm{~mm}$ (1.12. att.). 


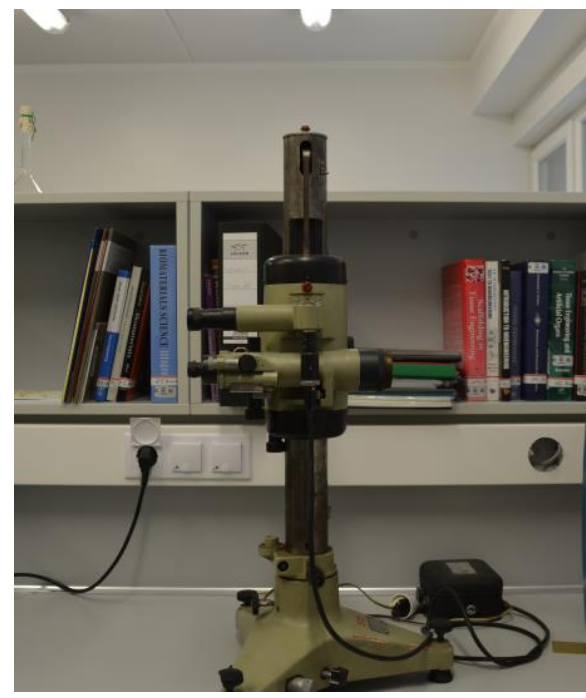

1.12. att. KM-6 katetometrs, mērījuma precizitāte $\pm 0,01 \mathrm{~mm}$

(fotogrāfija no darba autora personīgā arhīva)

Kaulu paraugi tika mērīti $550 \mathrm{~mm}$ attālumā no katetometra (1.13. att.).

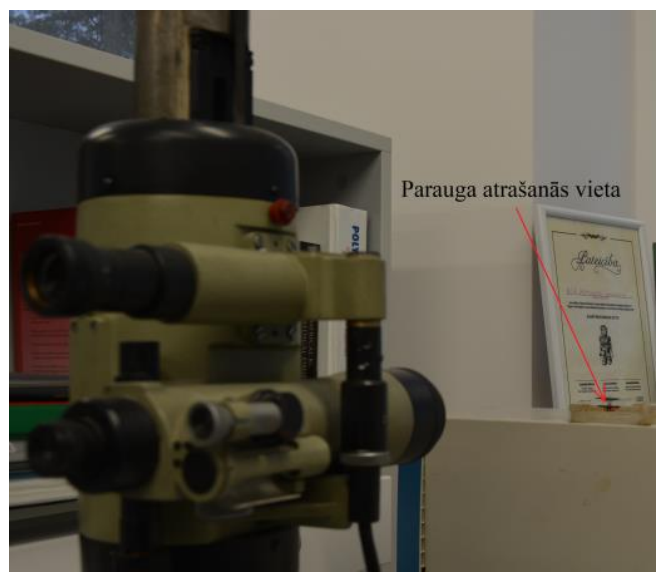

\subsection{3. att. Kaulu parauga platuma un biezuma mērījumu iegūšana}

(fotogrāfija no darba autora personīgā arhīva)

Paraugu lieces izpēte tika veikta stendā Zwick/Roell (BT1-FR2.5TN.D14, Vācija), kas aprīkots ar 2,50 $\pm 0,1 \mathrm{kN}$ spēka tenzodevēju (1.14. att.). 


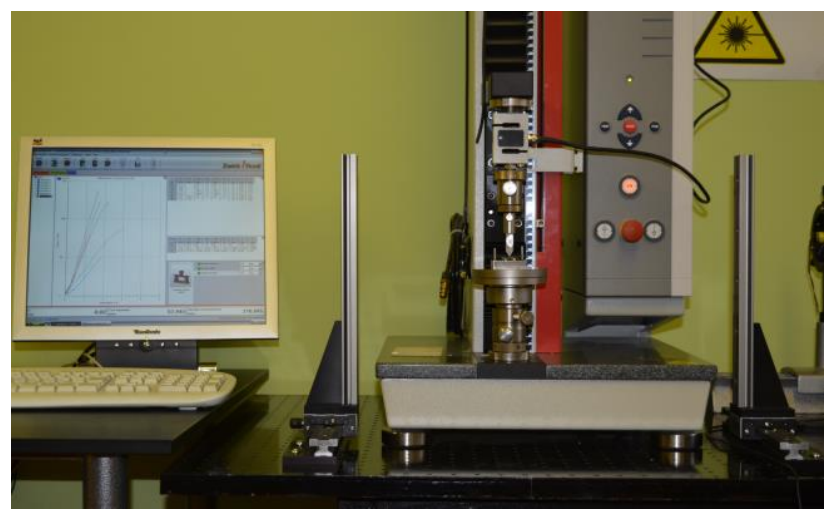

1.14. att. Zwick/Roell lieces izpētes stends

(fotogrāfija no darba autora personīgā arhīva)

Kaulu paraugi tika ielikti $10 \mathrm{~mm}$ attālumā starp atbalstiem (1.15. att.).

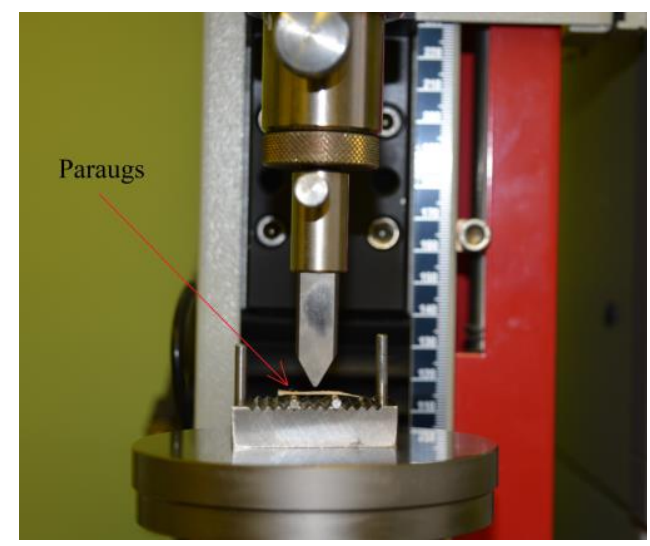

\subsection{5. att. Parauga izpēte par trīs punktu lieci}

(fotogrāfija no darba autora personīgā arhīva)

Stends tika izmantots kopā ar datorprogrammu testXpert 2.5 (Vācija), kas paredzēta testēšanas ierīces vadīšanai un datu apstrādei. Paraugi tika deformēti ar ātrumu $1 \mathrm{~mm} / \mathrm{min}$ līdz parauga sabrukšanai. Noslogojuma stendā iegūtie dati tika apstrādāti ar testXpert 2.5 programmu. 
Katrā sprieguma-deformācijas līknes punktā pēc stenda spiediena uzgaḷa pārvietošanas programma automātiski aprēķināja parauga nolieci. Pēc formulām, kuras tika ievadītas programmā, automātiski tika aprēķināts graujošais spriegums, graujošā deformācija un lieces modulis.

\subsubsection{Rentgenoloğiskā pētījuma metode}

Operēta un neoperēta augšstilba ķermeņa kortikālā kaula blīvums tika mērīts ar konusa staru datortomogrāfijas palīdzību, izmantojot iCAT Next Generation aparatūru (Kavo, Vācija), (1.16. att.).

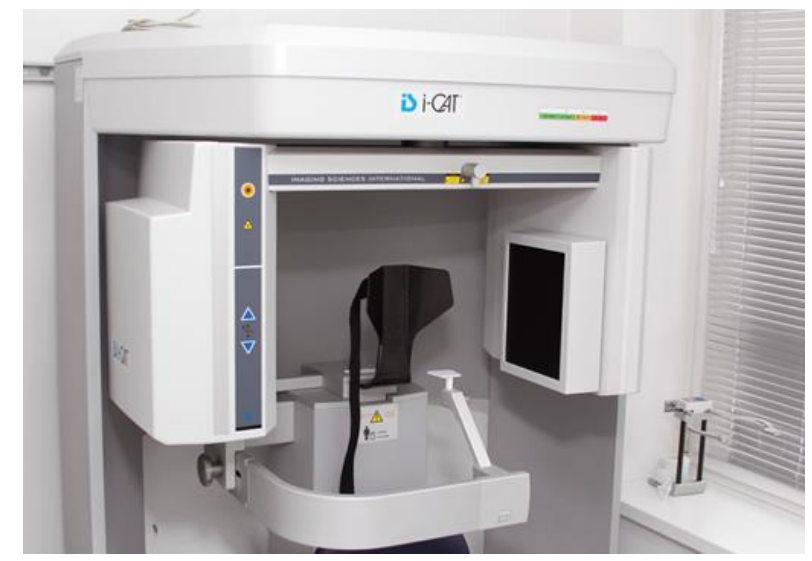

\subsection{6. att. iCAT Next Generation aparatūra konusa stara datortomogrāfijas attēla iegūšanai}

(fotogrāfija no darba autora personīgā arhīva)

Aparatūra tika izmantota, vadoties pēc standarta darbības protokola (spriegums $120 \mathrm{KV}$, strāvas stiprums $38 \mathrm{~mA}$, izmeklēšanas lauks (FOV) $17 \mathrm{~cm}$, izšķirtspēja 0,4 vokseḷi (trīsdimensiju attēla tilpuma mērvienība)). Iegūtie testa dati tika apstrādāti un analizēti, izmantojot aparatūrai specifisko programmatūru iCAT eXamVision (Kavo, Vācija). Paraugiem tika noteiktas attēla vokseḷa nomelnējuma līmeņa vērtības. Vērtības, kas tika parādītas Haunsfillda vienībās $(H U)$, tika pārveidotas $1: 1$ radioloǵiskās vokseḷa nomelnējuma līmeṇa vērtības 
vienībās (Do-Gyoon Kim, 2014). Attēla nomelnējuma līmeņa vērtība tika noteikta $4 \mathrm{~mm}^{2}$ lielā laukā (1.17. att.).

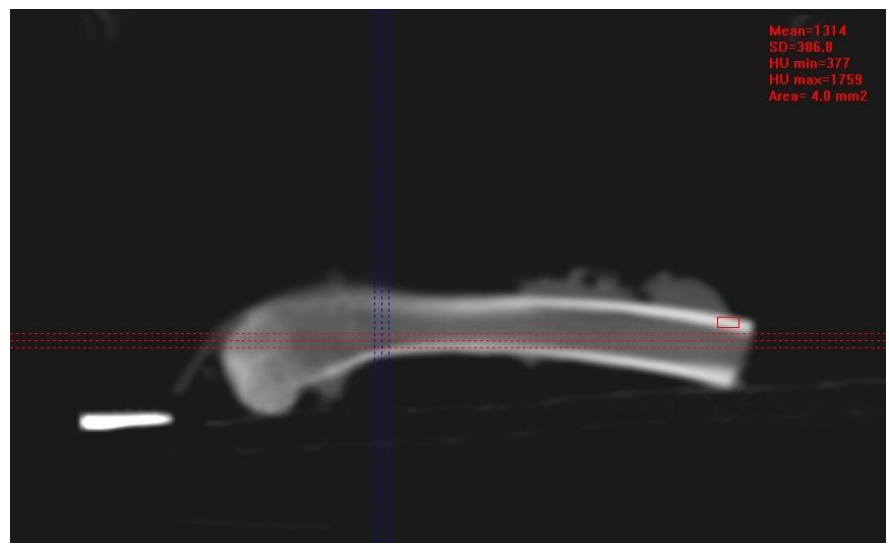

1.17. att. Konusa stara datortomogrāfijas attēls radiolog̣iskā attēla nomelnējuma blīvuma vērtības noteikšanai augšstilba ķermeņa kortikālajā kaulā - sagitālajā plaknē. Sarkanās līnijas - koronārā plakne, zilās līnijas

- aksiālā plakne. Ar sarkano taisnstūri atzīmēts izmeklējamais lauks.

Augšējā labajā stūrī var redzēt nosaukumus un parametrus:

Mean - vidējais kaula minerālblīvums izmeklējamā laukā; SD - standarta deviācija; HU min - minimālais kaula minerālblīvums izmeklējamā laukā;

HU max - maksimālais kaula minerālblīvums izmeklējamā laukā;

Area - izmeklējamā lauka lielums

\subsubsection{Morfoloğiskā pētījuma metode}

Pētījumā tika izmantota klasiskā audu sagatavošanas metode 33 kaulaudu paraugiem no apakšžokḷa premolāra rajona. Kaulaudu morfoloǵiskajai izpētei tika izmantota rutīnizmeklēšanas metode ar hematoksilīnu/eozīnu (Kiernan, 2015).

Pēc kaulaudu bloku izdalīšanas audi tika ievietoti fiksējošā škīidumā 10 \% formalīnā uz divām nedēḷām. Pēc fiksācijas kaulaudi tika dekalcinēti ar Osteodec šķīdumu (Bio-medica, Itālija), tad audi tika atūdeņoti, pielietojot 
etilspirtu, un attaukoti ksilola šķīdumā. Pēc tam audi tika ieguldīti kasetēs ar parafīnu, izveidojot parafīna blokus, no kuriem tika sagatavoti 3-5 $\mu \mathrm{m}$ biezi griezumi un uzklāti uz priekšmetstikliem turpmākai apstrādei un krāsošanai ar hematoksilīnu/eozīnu.

Trabekulārā kaula laukums tika izmērīts, izmantojot datorprogrammu Image Pro Plus 7 (Media Cybernetics, ASV). Visos kaulaudu paraugos pēc nejaušības principa tika izvēlēti trīs vienādi redzamības lauki $\left(0,975 \mathrm{~mm}^{2}\right)$.

\subsection{Datu statistiskās apstrādes metodes}

Visu datu statistiskā apstrāde, aprēḳināšana un grafiskais attēlojums tika veikts ar speciālas programmatūras GraphPad PRISM v.6.0e (GraphPad Software Inc., Sandjego, Kalifornija, ASV) palīdzību. Dispersijas homogenitāte tika pārbaudīta ar Brown-Forsythe un Bartiett testu palīizību. Nevienmērīga sadalījuma gadījumā dažādu grupu skaitlisko mainīgo vērtību vidējās vērtības tika salīdzinātas, izmantojot neparametrisko kritēriju ANOVA testu jeb KruskalWallis testu un kā post-hoc procedūru pēc tam pielietoja Benjamini, Krieger un Yekutieli metodi.

Visi rezultāti tika izteikti kā mediānas (Md) ar starpkvartiḷu diapazonu (IQR). Divi lielumi tika uzskatīti par statistiski nozīmīgi atškirīgiem, ja starpības ticamības līmenis starp tiem bija lielāks par $95 \%(\mathrm{p}<0,05)$. 


\section{Rezultāti}

\subsection{Biomehāniskā pētījuma un datu statistiskās apstrādes rezultāti augšstilba kaula paraugos}

Visi kaula paraugi, kuri tika izmantoti augšstilba kaulu biomehānisko parametru noteikšanai, tika iedalīti trīs grupās:

1) placebo ķirurgiijas grupa: labajā augšstilbā trochanter major rajonā tika radīts defekts, bet materiāls netika ielikts;

2) HAP/TCP grupa: labajā augšstilbā trochanter major rajonā defekts tika aizpildīts ar HAP/TCP (70/30) granulām;

3) HAP/TCP/5 \% Sr grupa: labajā augšstilbā trochanter major rajonā defekts tika aizpildīts ar HAP/TCP (70/30) granulām, kam pievienoti $5 \%$ stroncija.

\subsubsection{Graujošās deformācijas noteikšanas un datu statistiskās apstrādes rezultāti}

Operēta augšstilba placebo ķirurǵijas grupas paraugiem graujošā deformācija bija 1,43 (1,57-1,20) \%, kas ir statistiski ticamāki lielāks nekā HAP/TCP grupas paraugiem $1,16(1,18-1,13) \%, \mathrm{p}=0,002$, un HAP/TCP/5 \% $\mathrm{Sr}$ grupas paraugiem $1,04(1,14-0,86) \%, \mathrm{p}=0,005$. Tika atrastas statistiski ticamas graujošās deformācijas atškirīibas starp HAP/TCP un HAP/TCP/5 \% Sr grupas paraugiem: HAP/TCP grupas kaulu paraugu graujošā deformācija ir lielāka nekā HAP/TCP/5 \% Sr grupas kaulu paraugu graujošā deformācija, $\mathrm{p}=$ 0,02 (2.1. att.). 


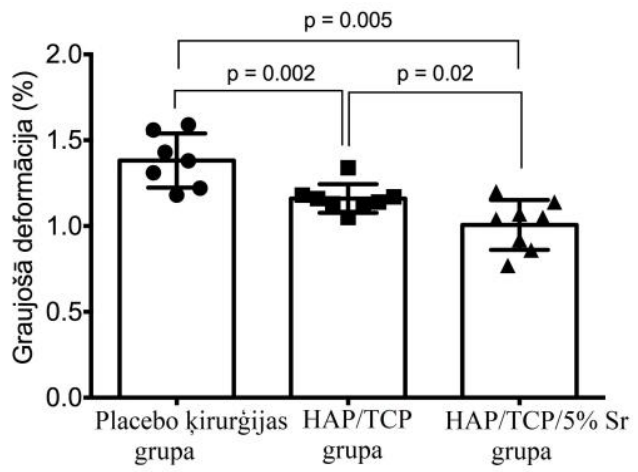

2.1. att. Operēta augšstilba paraugu graujošā deformācija dažādām grupām

Neoperēta augšstilba placebo ķirurǵijas grupas paraugiem graujošā deformācija bija 1,27 (1,42-1,17) \%, kas ir statistiski ticamāki lielāka nekā HAP/TCP grupas paraugiem 1,06 $(1,15-0,93) \%, \mathrm{p}=0,012$, un HAP/TCP/5 \% Sr grupas paraugiem 1,02 $(1,14-0,9) \%, \mathrm{p}=0,003$. Statistiski ticamas graujošās deformācijas atšķirības starp HAP/TCP un HAP/TCP/5 \% Sr grupas paraugiem netika atrastas, $p=0,64$ (2.2. att.).

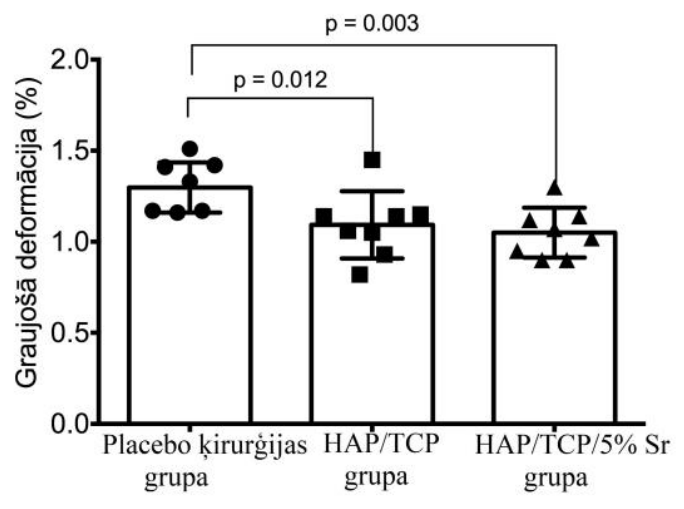

2.2. att. Neoperēta augšstilba paraugu graujošā deformācija dažādām grupām 


\subsubsection{Graujošā sprieguma noteikšanas un datu statistiskās apstrādes rezultāti}

Operēta augšstilba paraugu statistiski ticamas graujošā sprieguma atšķirības starp visām trim grupām paraugu lieces laikā netika konstatētas ( $p>0,05)$ : graujošā sprieguma lielums placebo ķirurǵijas grupas paraugiem bija 176,7 (216-154) MPa, HAP/TCP grupas paraugiem 194,6 (207,2 - 169,9) MPa un HAP/TCP/5 \% Sr grupas paraugiem 193,7 (208,1-176,1) MPa (2.3. att.).

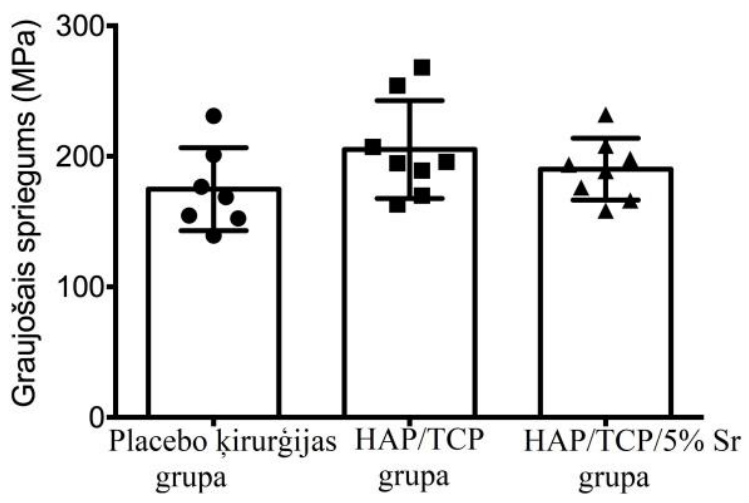

\section{3. att. Operēta augšstilba paraugu graujošais spriegums dažādām}

\section{grupām}

Neoperēta augšstilba placebo ķirurğijas grupas paraugiem graujošais spriegums bija 155,5 (174,7-140,8) MPa, kas ir statistiski ticami mazāks nekā HAP/TCP grupas paraugiem 209,2 (234,2-164,4) MPa, p = 0,017, un HAP/TCP/5 \% Sr grupas paraugiem 177,7 (200,3-165,5) MPa, p =0,026. Statistiski ticamas graujošā sprieguma atšksirības starp HAP/TCP un $\mathrm{HAP} / \mathrm{TCP} / 5 \% \mathrm{Sr}$ grupas paraugiem netika atrastas, $\mathrm{p}=0,46$ (2.4. att.). 


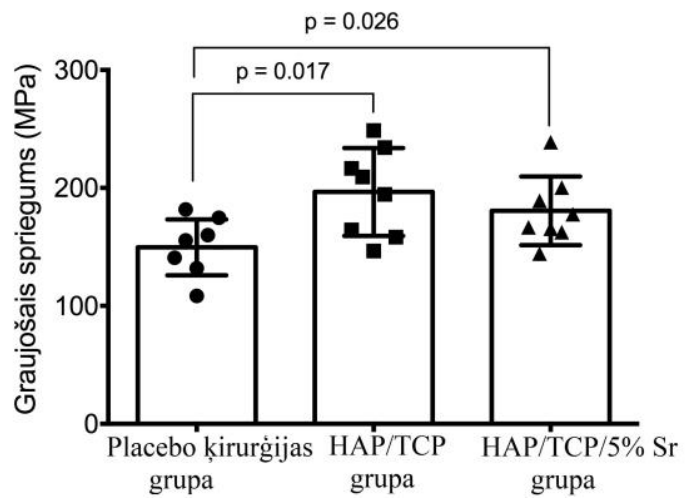

2.4. att. Neoperēta augšstilba paraugu graujošais spriegums dažādām grupām

\subsubsection{Lieces moduḷa noteikšanas un datu statistiskās apstrādes rezultāti}

Lieces modulis raksturo materiāla stingumu: jo lielāks ir lieces modulis, jo materiāls ir stingāks. Pētījuma rezultāti pierādīja, ka operēta augšstilba placebo ķirurğijas grupas paraugu lieces modulis bija 16,31 (18,66-12,15) GPa, kas ir statistiski ticami mazāks nekā HAP/TCP grupas paraugiem 19,87 $(21,10-17,94) \mathrm{GPa}, \mathrm{p}=0,01$, un HAP/TCP/5 \% Sr grupas paraugiem 21,88 (27,53-21,09) GPa, $\mathrm{p}=0,005$. Tika atrastas statistiski ticamas lieces moduḷa atšķirības starp HAPTCP un HAP/TCP/5 \% Sr grupas paraugiem: HAP/TCP grupas kaulu paraugu lieces modulis ir mazāks nekā HAP/TCP/5 \% Sr grupas kaulu paraugu lieces modulis, $\mathrm{p}=0,02$ (2.5. att.). 


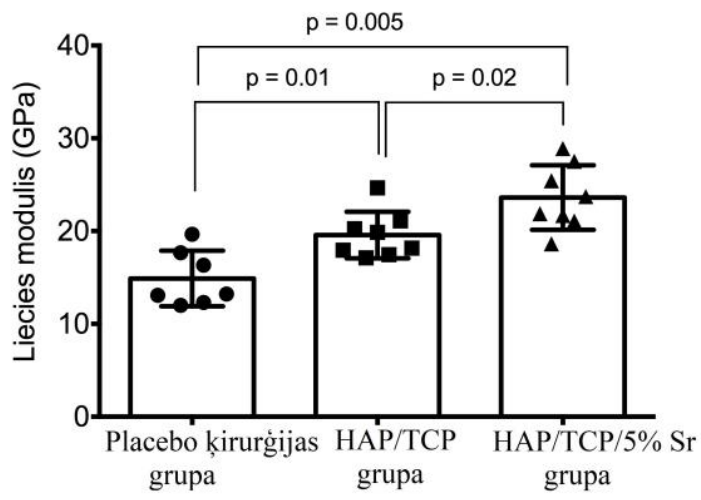

\section{5. att. Operēta augšstilba paraugu lieces modulis dažādām grupām}

Neoperēta augšstilba placebo kirurğijas grupas paraugu lieces modulis bija 14,91 (17,36-13,6) GPa, kas ir statistiski ticami mazāks nekā HAP/TCP grupas paraugiem 21,86 $(25,81-19,6) \mathrm{GPa}, \mathrm{p}=0,004$, un HAP/TCP/5 \% Sr grupas paraugiem 22,11 (23,41-20,29) GPa, $\mathrm{p}=0,006$. Statistiski ticamas lieces modula atškirīibas starp HAP/TCP un $\mathrm{HAP} / \mathrm{TCP} / 5 \% \mathrm{Sr}$ grupas paraugiem netika atrastas, $\mathrm{p}=0,87$ (2.6. att.).

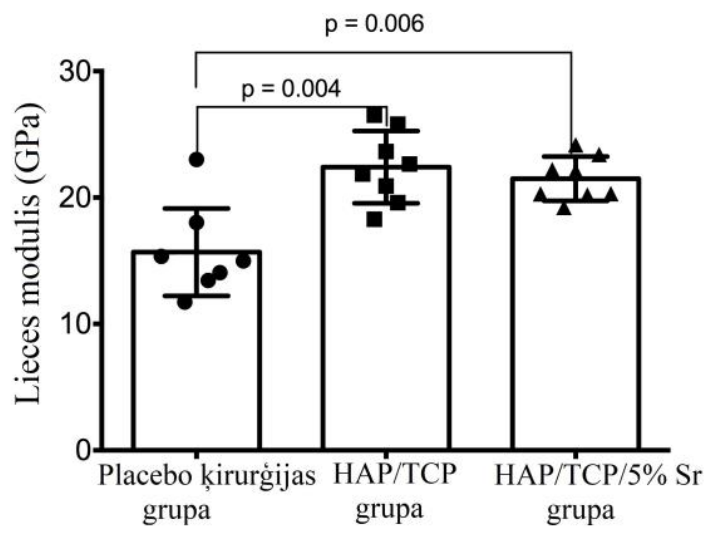

2.6. att. Neoperēta augšstilba paraugu lieces modulis dažādām grupām 


\subsection{Biomehāniskā pētījuma un datu statistiskās apstrādes rezultāti apakšžokḷa kaula paraugos}

Visi kaula paraugi, kuri tika izmantoti apakšžokḷa kaulu biomehānisko parametru noteikšanai, tika iedalīja trīs grupās:

1) placebo ķirurg̣ijas grupa: labajā augšstilbā trochanter major rajonā tika radīts defekts, bet materiāls netika ielikts;

2) HAP/TCP grupa: labajā augšstilbā trochanter major rajonā defekts tika aizpildīts ar HAP/TCP (70/30) granulām;

3) $\mathrm{HAP} / \mathrm{TCP} / 5 \% \mathrm{Sr}$ grupa: labajā augšstilbā trochanter major rajonā defekts tika aizpildīts ar HAP/TCP (70/30) granulām, kam pievienoti $5 \%$ stroncija.

\subsubsection{Graujošās deformācijas noteikšanas un datu statistiskās apstrādes rezultāti}

Placebo ķirurğijas grupas paraugiem graujošā deformācija bija 2,04 $(2,37-1,76) \%$, kas ir statistiski ticamāki lielāka nekā HAP/TCP grupas paraugiem $1,46(1,49-1,27) \%, \mathrm{p}=0.0003$, un $\mathrm{HAP} / \mathrm{TCP} / 5 \% \mathrm{Sr}$ grupas paraugiem $1,37(1,94-1,03) \%, p=0,02$. Statistiski ticamas graujošās deformācijas atšķirības starp HAP/TCP un HAP/TCP/5 \% Sr grupas paraugiem netika atrastas, $p>0,99$ (2.7. att.). 


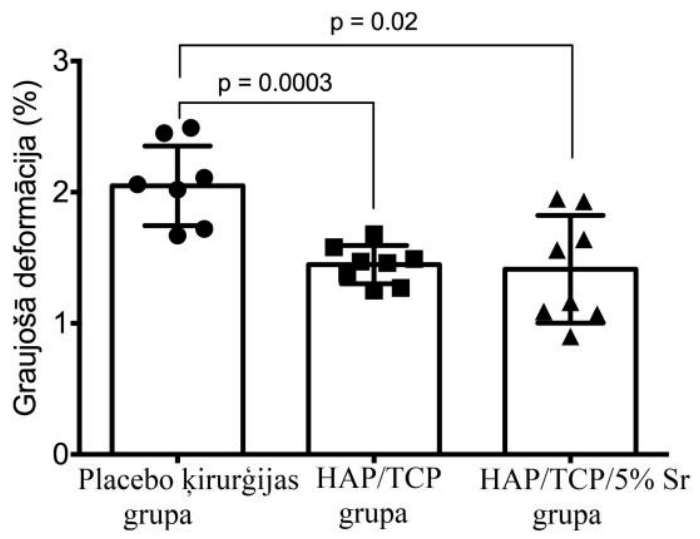

2.7. att. Apakšžokḷa kaula paraugu graujošā deformācija dažādām grupām

\subsubsection{Graujošā sprieguma noteikšanas un datu statistiskās apstrādes rezultāti}

Placebo ķirurgijas grupas paraugiem graujošais spriegums bija 89,36 (108,6-77,44) MPa, kas ir statistiski ticami mazāk nekā HAP/TCP grupas paraugiem $183(202,7-155,2) \mathrm{MPa}, \mathrm{p}=0,0003$, un $\mathrm{HAP} / \mathrm{TCP} / 5 \% \mathrm{Sr}$ grupas paraugiem 241,9 (250,9-234,9) MPa, p = 0,0007. Tika atrastas statistiski ticamas graujošā sprieguma atšķirības starp HAP/TCP un $\mathrm{HAP} / \mathrm{TCP} / 5$ \% $\mathrm{Sr}$ grupām: HAP/TCP grupas kaulu paraugu graujošais spriegums ir mazāks nekā $\mathrm{HAP} / \mathrm{TCP} / 5 \% \mathrm{Sr}$ grupas kaulu paraugu graujošais spriegums, $\mathrm{p}=0,022$ (2.8. att.). 


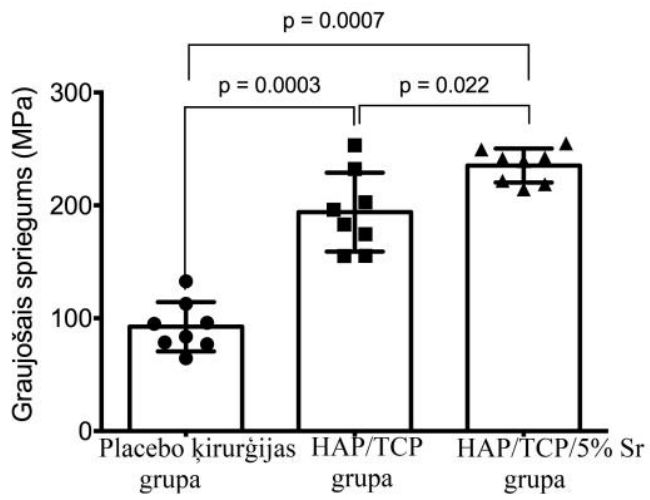

2.8. att. Apakšžokḷa kaula paraugu graujošais spriegums dažādām grupām

\subsubsection{Lieces moduḷa noteikšanas un datu statistiskās apstrādes} rezultāti

Placebo ķirurǵijas grupas paraugu lieces modulis bija 5,25 (7,23-4,35) GPa, kas ir statistiski ticami mazāks nekā HAP/TCP grupas paraugiem 12,44 $(17,71-11,55) \mathrm{GPa}, \mathrm{p}=0,0003$, un $\mathrm{HAP} / \mathrm{TCP} / 5 \% \mathrm{Sr}$ grupas paraugiem 15,83 $(20,8-14,67) \mathrm{GPa}, \mathrm{p}=0,0007$. Statistiski ticamas lieces moduḷa atšķirības starp HAP/TCP un HAP/TCP/5 \% Sr grupas paraugiem netika atrastas, $\mathrm{p}=0,29$ (2.9. att.).

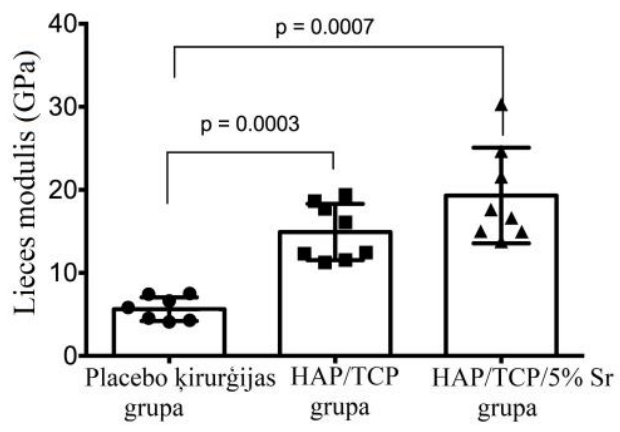

2.9. att. Apakšžokḷa kaula paraugu lieces modulis dažādām grupām 


\subsection{Rentgenoloğiskā pētījuma un datu statistiskās apstrādes rezultāti augšstilba kaula paraugos}

Visi kaula paraugi, kuri tika izmantoti augšstilba kaulu minerālblīvuma noteikšanai, tika iedalīit trīs grupās:

1) placebo ķirurğijas grupa: labajā augšstilbā trochanter major rajonā tika uztaisīts defekts, bet materiāls netiek ielikts;

2) HAP/TCP grupa: labajā augšstilbā trochanter major rajonā defekts tika aizpildīts ar HAP/TCP (70/30) granulām;

3) $\mathrm{HAP} / \mathrm{TCP} / 5 \% \mathrm{Sr}$ grupa: labajā augšstilbā trochanter major rajonā defekts tika aizpildīts ar HAP/TCP (70/30) granulām, kam pievienoti $5 \%$ stroncija.

Operētā augšstilba placebo ķirurǵijas grupas paraugiem kortikālā kaula blīvums bija $923(1056-843,5)$ HU, kas ir statistiski ticami mazāks nekā HAP/TCP grupas paraugiem 1302 (1350-1209) HU, p $=0,016$, un HAP/TCP/5 \% Sr grupas paraugiem 1344 (1459-1156) HU, p = 0,042. Statistiski ticamas kortikālā kaula blīvuma atšķirības starp HAP/TCP un HAP/TCP/5 \% Sr grupas paraugiem netika atrastas, $\mathrm{p}=0,761$ (2.10. att.).

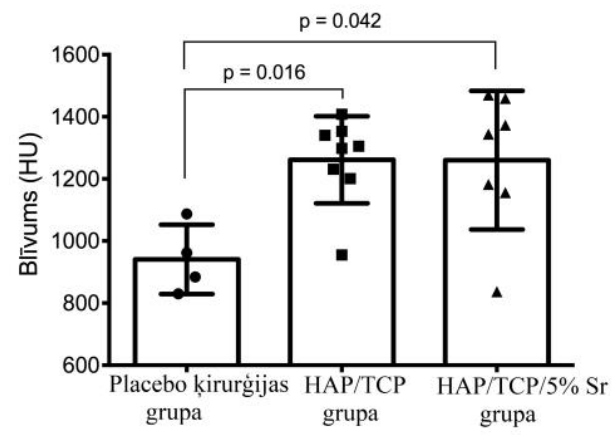

2.10. att. Operēta augšstilba paraugu kortikālā kaula blīvums dažādām grupām 
Neoperēta augšstilba placebo ķirurǵijas grupas paraugiem kortikālā kaula blīvums bija 935,5 (1053-876) HU, kas ir statistiski ticami mazāks nekā HAP/TCP grupas paraugiem 1212 (1360-1138) HU, p $=0,016$, un HAP/TCP/5 \% Sr grupas paraugiem 1261 (1315 - 1090) HU, p = 0,012. Statistiski ticamas kortikālā kaula blīvuma atšķirības starp HAP/TCP un HAP/TCP/5\% Sr grupas paraugiem netika atrastas, $\mathrm{p}>0,99$ (2.11. att.).

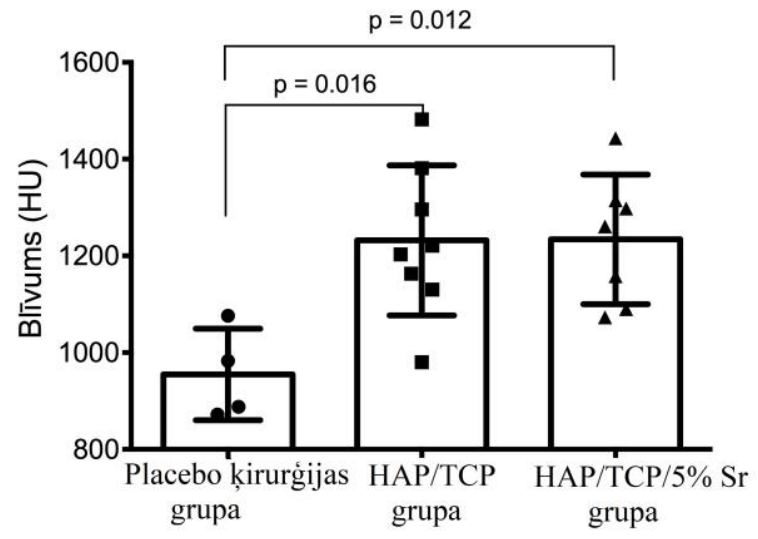

2.11. att. Neoperēta augšstilba paraugu kortikālā kaula blīvums dažādām grupām

\subsection{Rentgenoloğiskā pētījuma un datu statistiskās apstrādes rezultāti apakšžokḷa kaula paraugos}

Visi kaula paraugi, kuri tika izmantoti apakšžokḷa kaulu minerālblīvuma noteikšanai, tika iedalīti trīs grupās:

1) placebo ķirurğijas grupa: labajā augšstilbā trochanter major rajonā tika uztaisīts defekts, bet materiāls netiek ielikts;

2) HAP/TCP grupa: labajā augšstilbā trochanter major rajonā defekts tika aizpildīts ar HAP/TCP (70/30) granulām; 
3) HAP/TCP/5\% Sr grupa: labajā augšstilbā trochanter major rajonā defekts tika aizpildīts ar HAP/TCP (70/30) granulām, kam pievienoti $5 \%$ stroncija.

Placebo ķirurgijijas grupas paraugiem kortikālā kaula blīvums bija 709,5 (807-645) HU, kas ir statistiski ticami mazāk nekā HAP/TCP grupas paraugiem 871 (1047-829) HU, p = 0,024, un HAP/TCP/5\% Sr grupas paraugiem 916 (962-876) HU, p = 0,006. Statistiski ticamas kortikālā kaula blīvuma atšķirības starp HAP/TCP un HAP/TCP/5 \% Sr grupas paraugiem netika atrastas, $\mathrm{p}=0,522$ (2.12. att.).

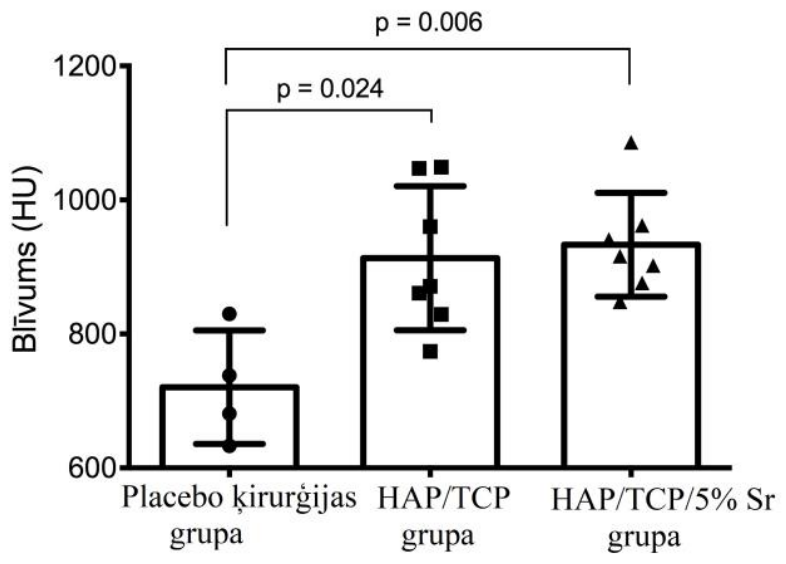

2.12. att. Apakšžokḷa kaula paraugu kortikālā kaula blīvums dažādām grupām 


\subsection{Operēta un neoperēta augšstilba biomehānisko parametru un minerālblīvuma salīdzinājums pēc dažāda biomateriāla implantācijas}

Visi kaula paraugi, kuri tika izmantoti operēta un neoperēta augšstilba kaulu biomehānisko parametru un blīvuma salīdzināšanai, tika iedalīja četrās grupās:

1) HAP/TCP LA grupa: operēta augšstilba kaulu paraugi - labajā augšstilbā trochanter major rajonā defekti tika aizpildīti ar HAP/TCP (70/30) granulām;

2) HAP/TCP KA grupa: neoperēta augšstilba kaulu paraugi - labajā augšstilbā trochanter major rajonā defekts netika aizpildīts ar HAP/TCP (70/30) granulām;

3) $\mathrm{HAP} / \mathrm{TCP} / 5 \%$ Sr LA grupa: operēta augšstilba kaulu paraugi - labajā augšstilbā trochanter major rajonā defekts tika aizpildīts ar HAP/TCP (70/30) granulām, kam pievienoti $5 \%$ stroncija.

4) $\mathrm{HAP} / \mathrm{TCP} / 5 \% \mathrm{Sr}$ LA grupa: neoperēta augšstilba kaulu paraugi - labajā augšstilbā trochanter major rajonā defekts tika aizpildīts ar HAP/TCP (70/30) granulām, kam pievienoti $5 \%$ stroncija.

Salīdzinot operētu un neoperētu augšstilba kaulu paraugu graujošo deformāciju, graujošo spriegumu, elastības moduli un blīvumu, netika atrastas statistiski ticamas atškirīības ( $\mathrm{p}>0,05),(2.13 .-2.16$. att.). 


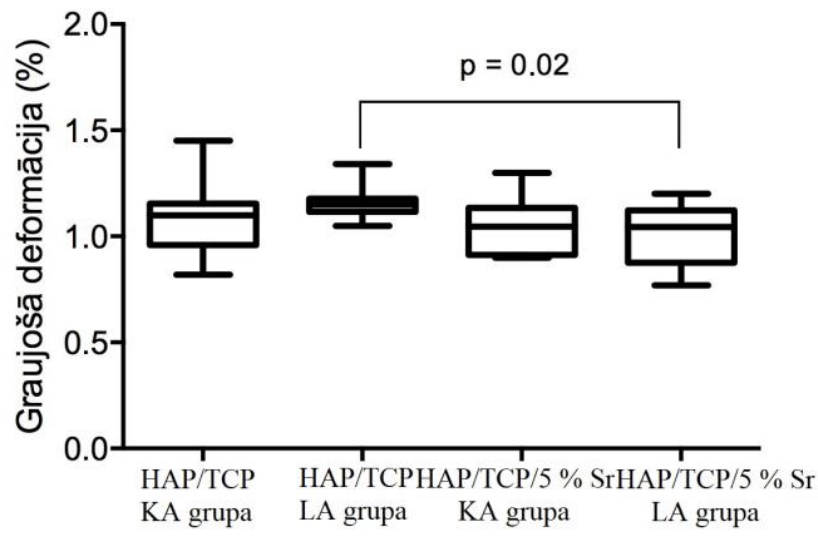

2.13. att. Operēta un neoperēta augšstilba paraugu graujošās deformācijas salīdzinājums pēc dažāda biomateriāla implantācijas

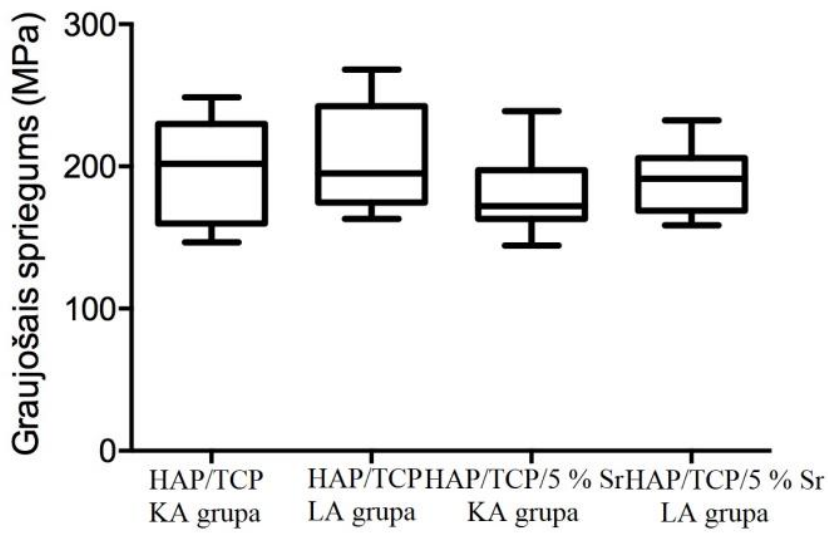

2.14. att. Operēta un neoperēta augšstilba paraugu graujošā sprieguma salīdzinājums pēc dažāda biomateriāla implantācijas 


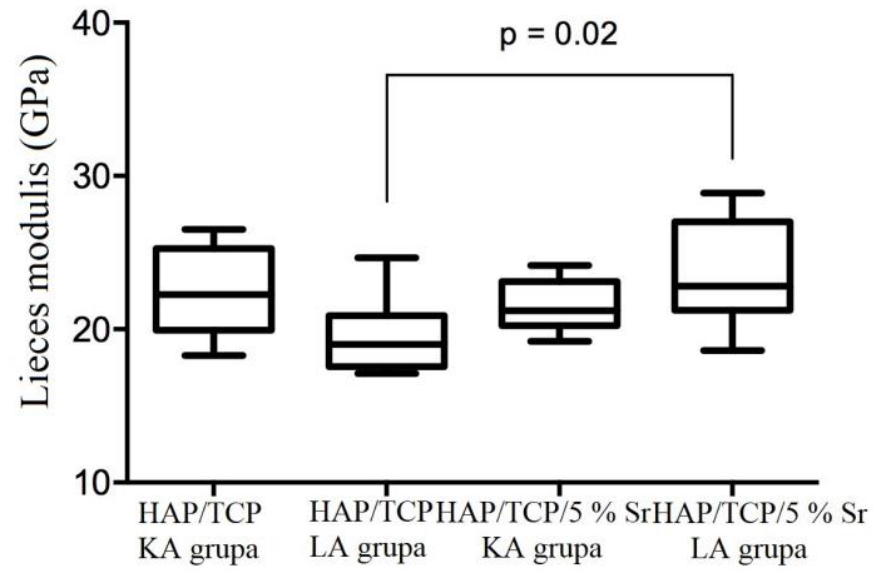

2.15. att. Operēta un neoperēta augšstilba paraugu lieces moduḷa salīdzinājums pēc dažāda biomateriāla implantācijas

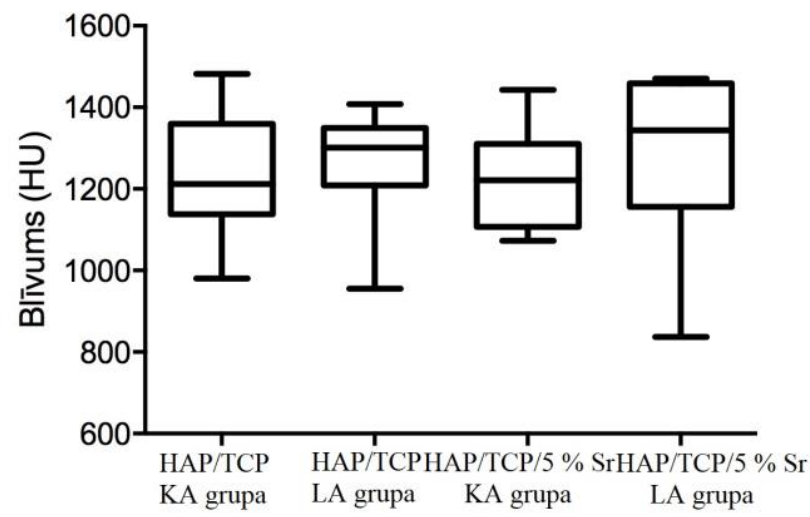

2.16. att. Operēta un neoperēta augšstilba paraugu minerālblīvuma salīdzinājums pēc dažāda biomateriāla implantācijas 


\subsection{Morfoloğiskā pētījuma un datu statistiskās apstrādes rezultāti apakšžokḷa kaula paraugos}

Visi kaula paraugi, kuri tika izmantoti apakšžokḷa trabekulāra kaula laukuma noteikšanai, tika iedalīja četrās grupās:

1) kontroles grupa: veseli truši;

2) placebo ķirurğijas grupa: labajā augšstilbā trochanter major rajonā tika radīts defekts, bet materiāls netika ielikts;

3) HAP/TCP grupa: labajā augšstilbā trochanter major rajonā defekts tika aizpildīts ar HAP/TCP (70/30) granulām;

4) $\mathrm{HAP} / \mathrm{TCP} / 5 \%$ Sr grupa: labajā augšstilbā trochanter major rajonā defekts tika aizpildīts ar HAP/TCP (70/30) granulām, kam pievienoti $5 \%$ stroncija.

Trabekulārā kaula laukums kontroles grupas paraugiem bija lielāks, salīdzinot ar osteoporozes grupu (placebo kiirurǵijas grupas, HAP/TCP grupas, HAP/TCP5\% Sr grupas) paraugiem. Trabekulārā kaula laukums kontroles grupā bija $0,20 \mathrm{~mm}^{2}\left(0,176-0,233 \mathrm{~mm}^{2}\right)$, kas ir statistiski ticami lielāks $(\mathrm{p}<0,0001)$ nekā HAP/TCP grupā $\left(0,127 \mathrm{~mm}^{2} ; 0,118-0,149 \mathrm{~mm}^{2}\right)$, HAP/TCP/5 \% Sr grupā $\left(0,136 \mathrm{~mm}^{2} ; 0,108-0,166 \mathrm{~mm}^{2}\right)$ un placebo ķirurgijijas grupā $\left(0,135 \mathrm{~mm}^{2} ; 0,126-\right.$ $0,164 \mathrm{~mm}^{2}$ ). Statistiski ticamas atšķirības starp HAP/TCP, HAP/TCP/5 \% Sr un placebo ķirurğijas grupām netika atrastas, $\mathrm{p}>0,05$ (2.17. att.). 


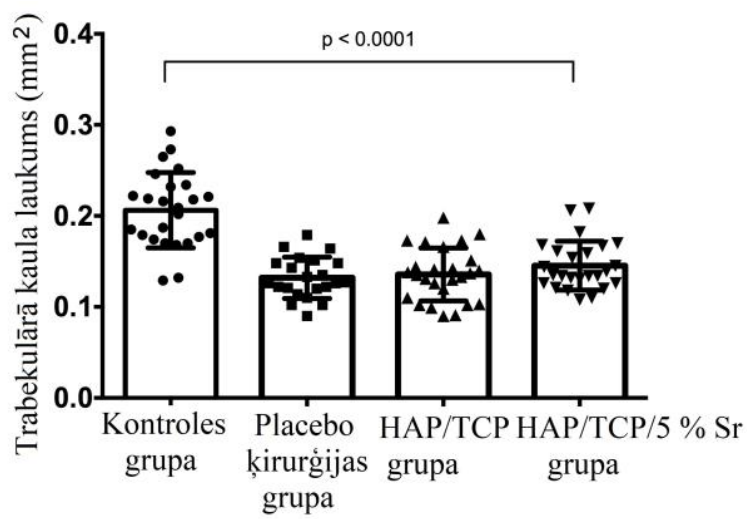

2.17. att. Trabekulārā kaula laukums dažādām pētījuma grupām 


\section{Diskusija}

Darbs tika realizēts Valsts pētījumu programmas Nr. 2014.10-4/VPP3/21 "Daudzfunkcionālie materiāli un kompozīti, fotonika un nanotehnologijas", projekts Nr. 4 "Nanomateriāli un nanotehnoloğijas medicīniskajam pielietojumam”, ietvaros, un tas ir liela projekta sastāvdaḷa, kura mērķis ir radīt un izpētīt jaunus, pielietojamus un konkurētspējīgus biomateriālus nanostrukturētus kompozītmateriālus osteoporotisku kaulaudu pastiprināšanai un aizvietošanai. Pieaugot dzīves līmenim, katra valsts saskaras ar sabiedrības novecošanas problēmu risināšanu, kas saistîta ar cilvēkiem, kuru dzīves kvalitāte ir atkarīga no balsta un kustību sistēmas slimību izraisītiem kaulu funkciju traucējumiem, kas ir otrs izplatītākais cēlonis invaliditātei globālā līmenī (Sözen et al., 2017). Pēc Eiropas Savienības datiem, Latvijā apmēram 33 \% iedzīvotāju (t. i., 700000 cilvēku) sirgst ar balsta un kustības sistēmas slimībām, tādām kā osteoporoze, reimatoīdais artrīts, osteoartrīts, spondiloze, podagra, un vairāk nekā 200 citu slimību, kurām ir hroniska gaita un kuru dēḷ cilvēks ātri kḷūst par darba nespējīgu invalīdu.

Līdztekus osteoporozes vispārējai medikamentozai ārstēšanai pēdējā laikā notiek pētîjumi par osteoporotiskā kaula pastiprināšanu lūzumu profilaksei biežākajās potenciālajās lūzumu vietās (Cosman et al., 2014; Iaquinta et al., 2019). Iaquinta et al. apskatā tika ņemti vērā dažādi audu inženierijas aspekti, kas tika izmantoti kaulu inženierijā. Tiek implantēti visvairāk izpētītie kaulaudus aizvietojošie materiāli, kas tiek modificēti, lai izstrādātu jaunas struktūras un tehnologijas. Arī mūsu pētījumā, kas tika realizēts VPP projekta ietvaros, tika paredzēts izpētīt jaunus multifunkcionālus materiālus un metodes kaulaudu apjoma un mehānisko īpašību pastiprināšanai, kaulaudu remineralizācijai un kaulaudu reosifikācijai, kaulaudu remodelāciju pavēršot vēlamajā virzienā - no atrofijas uz kaula jaunveidošanos - osteoporotisku kaulu ārstēšanu un 
osteoporozes profilaksi, papildinot iepriekš pētìtos un klīnikā pielietojamos divfāžu kalcija fosfātu biokeramikas materiālus ar stroncija joniem.

Biosaderīgu biomateriālu izstrādē nozīmīga loma ir in vivo novērojumiem, jo tikai pēc pozitīva atzinuma par materiāla biosaderību materiāls var tikt virzīts tālākiem klīniskiem pētījumiem. Pirms in vivo pētījumiem notiek stingra piemērotāko biomateriālu atlase in vitro pētījumiem, pielietojot šūnu kultūras. Tiek izmantotas dažādas metodes dzīvnieku osteoporozes ierosināšanai, starp kurām visplašāk izplatîta ir dzīvnieku sieviešu dzimtes bilaterālā ovariektomija. Citas metodes, kuras parasti izmanto osteoporozes ierosināšanai, ir imobilizācija, diētas maiņa un glikokortikoīdu ievadīšana (Calciolari et al., 2017). Līdzīgas osteoporozes ierosināšanas metodes ir izmantotas arī mūsu petījumā.

Pēcmenopauzes osteoporozes imitēšanai tiek izmantoti vairāki dz̄ivnieku modeḷi, galvenokārt grauzēji (Kalu, 1991; Turner, 2001). Žurkas un peles parasti tiek izmantotas zemās cenas, turēšanas un pārvadāšanas ērtuma dẹl, bet tās nesasniedz pilnīgu skeleta briedumu, kauliem nav Haversa kanālu sistēmas, ir mazizteikta remodelēšanās kortikālajā kaulā. Šie apstākḷi ierobežo žurku un peḷu izmantošanu osteoporozes pētījumos, īpaši kaulaudu minerālblīvumu ietekmējošu medikamentu izpētē, kas pieprasa kortikālā un trabekulārā kaula remodelēšanās dinamikas novērtēšanu. Wanderman et al. savā pētījumā secināja, ka mazāku dzīvnieku izmantošana apgrūtina implantācijas operāciju tehniskā ziņā, kā arī grūti izvērtēt osteoporozes medikamentu efektivitāti kaulaudu uzbūves īpatn̄̄bu dēl (Wanderman et al., 2018). Savukārt Kimmel pētījuma dati liecina, ka lielāku dzīvnieku (piem., suņu, aitu, pērtiķu) izmantošana eksperimentālajās operācijās tehnoloǵiskā ziṇā tās vairāk tuvinātu cilvēku operācijām, bet tās nav iespējams tehnisku iemeslu dēḷ un pieškirtā finansējuma ietvaros (Kimmel, 2001). Castaneda et al. biomateriālu pētījumos rekomendē izmantot trušus, jo viņiem ir aktīva kaulaudu remodelēšanās. Trušu un cilvēku 
audos novērojamās morfoloǵiskās pārmaiņas ir līdzīgas un salīdzināmas. Truši ir labs modelis eksperimentālas osteoporozes pētījumiem, jo sasniedz skeleta briedumu 7-8 mēnešos un tiem ir ievērojama remodelēšanās kortikālajā kaulā (Castaneda et al., 2008). Mūsu eksperimentālajā pētījumā kā dzīvnieku modelis tika izmantoti truši.

Analizējot literatūras avotus, netika atrasts neviens pētījums, kurā tikuši salīdzināti kaulaudu biomehāniskie parametri vai minerālblīvums blakus biomateriāla implantācijas vietai un attālināti no tās, kā osteoporozes modeli izmantojot dzīvniekus. Turklāt bieži vien tajos analizēti kaulu paraugi no divām vai trim dzīvnieku grupām. Mūsu pētījumu var uzskatīt par unikālu, jo tika analizēti 102 kaulaudu paraugi no 13 dažādām dzīvnieku grupām, salīdzinot kaulaudu paraugus pēc divfāžu kalcija fosfāta biokeramikas implantācijas ar vai bez stroncija klātbūtnes ar placebo ķirurgijias un kontroles grupas kaulaudu paraugiem trušiem ar eksperimentālo osteoporozi. Tika izvērtēti biomehāniski parametri (graujošā deformācija, graujošais spriegums un elastîbas modulis) un minerālblīvums osteoporotisku kaulu paraugiem. Kaulu paraugi tika ņemti no operēta augšstilba ķermeṇa dą̧as pēc iespējas tuvāk implantācijas vietai, lai noteiktu lokālu biomateriāla ietekmi, kā arī no neoperēta augšstilba ķermeņa daḷas un apakšžokḷa kaula leņķa rajona, lai noteiktu sistēmisku biomateriāla iedarbību.

Lai pierādītu osteoporozi, tika noteikts trabekulārā kaula laukums apakšžokḷa kaula premolārā rajonā trušiem ar eksperimentālo osteoporozi un veseliem dzīvniekiem. Tika novērotas statistiski ticamas atškirīības veseliem un osteoporotiskiem trušiem: trabekulārā kaula laukums veseliem trušiem bija $0,20 \mathrm{~mm}^{2}$, savukārt osteoporotiskiem trušiem variēja no $0,127 \mathrm{~mm}^{2}$ līdz $0,136 \mathrm{~mm}^{2}$, kas ir statistiski ticami mazāks, salīdzinot ar veselo trušu trabekulāro kaulu laukumu. Mūsu pētījumā netika atrastas statistiski ticamas trabekulārā kaula laukuma atšķirības starp osteoporotisku dzīvnieku grupām trīs mēnešus 
pēc biomateriāla implantācijas un placebo ķirurgijijas. Līdzīgi rezultāti ir Baier et al. pētījumā, kurā tika salīdzināts kalcija fosfāta cements ar stronciju saturošo kacija fosfâta cementu, ņemot vērā to lokālo un sistēmisko iedarbību uz kaulaudiem eksperimentālā osteoporozes dzīvnieku modelī. Savā pētījumā autors konstatēja līdzīgu kaulaudu apjomu vienu un trīs mēnešus pēc kalcija fosfātu saturoša biomateriāla implantācijas ar vai bez stroncija klātbūtnes. Taču, analizējot žurku kaulu paraugus pēc sešiem mēnešiem, lielākais trabekulārā kaula apjoms bija stronciju saturošo biomateriālu grupā (Baier et al., 2013). Tas tika apstiprināts arī Ni et al. pētījumā, kurā, izmantojot trušu modeli, stronciju saturošs hidroksiapatīta cements tika izmantots primārā gūžas locītavas protezēšanā. Autora darbā tika konstatēts, ka pēc sešiem mēnešiem stroncija klātbūtnē veidojas lielāks kaula apjoms, salīdzinot ar trušu grupu, kur kā kaulu aizvietojošais biomateriāls tika izmantots polimetilmetakrilāta cements ( $N i$ et al., 2006). Mūsu un citu autoru iegūtie dati liecina par to, ka jaunveidoto kaulu apjoms stronciju jonu ietekmes rezultātā ir atkarīgs no laika perioda pēc implantācijas.

No dažādiem pieejamajiem kaulaudu aizvietošanas biomateriāliem tikai autologiem kaula transplantātiem piemīt osteokonduktīvas, osteoinduktīvas un osteogēnas īpašības (Sakkas et al., 2017). Tomēr šim biomateriālam piemīt neparedzamas resorbcijas īpašības, tas ir pieejams ierobežotā daudzumā, un pastāv inficēšanas risks (Nkenke et al., 2014; Jensen et al., 2016). Tādēḷ liela uzmanība tiek pievērsta biokeramisko materiālu (hidroksiapatīta)pētniecībai, šiem materiāliem jābūt ar bioloǵiskas saderība, osteovadītspējas un bionoārdīšanās īpašībām. Schlickewei et al. pētījumā izveidoti defekti veselo trušu apakšstilba kaulā tika pildīti ar HAP biokeramikas granulām. Pēc 12 nedēḷām tika novērota kaulaudu jaunveidošanās. Dzīvnieku kaulā ieauga kaula transplantāts, un uz tā virsmas izveidojās jauns kauls (Schlickewei et al., 2015). Mūsu pētījuma darba rezultātos var novērot kaulu biomehānisku 
parametru uzlabojumu un minerālblīvuma palielināšanos eksperimentālo dz̄ivnieku grupām pēc biomateriāla implantācijas. Savukārt līdzīgais trabekulārāā kaula laukums visām osteoporotisko dzīvnieku grupām liecina par nemainīgu kaula apjomu.

Divfāzu kalcija fosfāta biomateriālus var izmantot kā kaulaudu aizvietošanas materiālus, lai stiprinātu osteoporotisko kaulu un uzlabotu kaulaudu dzī̌anu (Salma et al., 2013). Sulaiman et al. savā pētījumā secināja, ka 80 \% trikacija fosfāta un $20 \%$ hidroksiapatìta kombinācija nodrošina mehānisku izturību un veido 60-70 \% kaulaudu. Trikalcija fosfâts kalpo kā bagāts kalcija un fosfora avots, kas var viegli asimilēties un absorbēties (Sulaiman et al., 2013). Tas ir ḷoti bioloǵiski saderīgs, izveido resorbējošu bloḳēšanas tīklu defekta vietā, lai veicinātu sadzīšanu un nodrošinātu sākotnēju kalcija un ortofosfāta jonu izdalīšanos asinsvados, tādējādi nodrošinot jaunu kaulu veidošanos (Sulaiman et al., 2013; Salma et al., 2015). Ishakawa et al. pētījumā salīdzināja trīs komerciālus kaulaudu aizstājējus ar dažādu sastāvu: hidroksiapatītu (HAP, Neobone $\left.{ }^{\circledR}\right)$, karbonāta apatītu $\left(\mathrm{CO}_{3} \mathrm{AP}, \mathrm{Cytrans}{ }^{\circledR}\right)$ un trikalcija fosfātu (TCP, Cerasorb $\left.{ }^{\circledR}\right)$. Pētījuma rezultāti parādīja, ka jauna kaula veidošana un kaula aizstājēja resorbcija ir atkarīga no biomateriāla veida. HAP gadījumā 4 nedēḷas pēc implantācijas jaunu kaulu veidošanās esošā kaula apkārtnē bija ierobežota un jauna kaula daudzums bija ḷoti mazs, 12. nedẹ̄̂ā kaulu daudzums bija gandrīz tāds pats. Atšḳirībā no HAP, $\mathrm{CO}_{3} \mathrm{AP}$ gadījumā gan 4., gan 12. nedēḷā tika izveidots daudz lielāks kaulaudu daudzums. Lielāku $\mathrm{CO}_{3} \mathrm{AP}$ granulu daḷu 12. nedệ̄ā daḷēji nomainīja jaunizveidoti kaulaudi. Interesanti dati bija TCP gadījumā, kad 4. nedẹḷā gandrīz netika novērota kaulaudu veidošanās - materiāls palika pie kaula defekta, bet 12 nedēḷas pēc biomateriāla implantācijas izveidojās liels kaulaudu daudzums un lielākā daḷa materiāla šajā laikā tika absorbēta (Ishakawa et al., 2010). Ar šo darbu autoru rezultātiem ir pamatoti mūsu pētījumā izmantoto biomateriālu izvēle: HAP biokeramikas sastāvā tika 
izmantots, lai jaunizveidotam kaulam nodrošinātu mehānisku izturību, savukārt TCP nodrošina jauna kaula veidošanos.

Lielākais kalcija fosfāta biomateriālu daudzums nav viendabīgs un satur mikroelementus, kuriem ir būtiska loma augšanā un kaulu atjaunošanā (Ehret et al., 2017). Stroncijs pēc biologiskajām īpašībām ir līdzīgs kalcijam, tādēl uzkrājas kaulos. Agrāk stroncija ranelāts tika pielietots osteoporozes sistēmiskā ārstēšanā (piem., Protelos, Francija), bet tā biopieejamība ievērojami samazinās (par 60-70\%) atkarībā no pacienta uztura režīma. Sistēmiskajai stroncija ranelāta lietošanai ir arī vairākas nopietnas blaknes - gremošanas traucējumi, psihiskas izmainas, venoza tromboze un miokarda infarkts (Jonville-Bera et al., 2011). Hao et al. pētījums parādīja, ka stroncijs varētu uzlabot mezenhimālo cilmes šūnu osteogēno diferenciāciju un kaulu veidošanos in vivo, kā arī samazināt osteoklastu skaitu un aktivitāti (Hao et al., 2015). Tā kā stroncijs darbojas kā duāls aǵents, optimālais stroncija daudzums joprojām ir pētniecības jautājums. Kā aprakstīts literatūrā, stroncija daudzums biokeramikā ir robežās no $1 \%$ līdz 100 \% (Ehret et al., 2017). Saint-Jean et al. savā pētījumā pierādīja, ka zema stroncija koncentrācija biomateriālos samazina kaulu resorbciju un stimulē kaulu veidošanos (Saint-Jean et al., 2005). Līdzīgi Grynpas et al. pētījumā, žurku mugurkaula skriemeḷu tilpums palielinājās par 17\% (Grynpas et al., 1996). Arī mūsu pētījumā biomateriāli ar nelielu stroncija daudzumu, uzlaboja kaulu biomehāniskās īpašības, salīdzinot ar pārējām osteoporotisku dzīvnvieku grupām. Savukārt, netika atrastas statistiski ticamas kaulu minerālblīvuma atšķirīibas pēc biomateriāla implantācijas ar vai bez stroncija klātbūtnes.

Literatūras datos ir pierādīts, ka lielākas Sr devas izraisa pretēju efektu, kavējot kaulaudu mineralizācijas procesu (Grynpas et al., 1996). Līdzīga negatīva ietekme tika novērota in vitro osteoblastos, kur lielākas Sr devas (> $20 \mu \mathrm{g} / \mathrm{ml}$ ) traucēja hidroksilapatīta veidošanos, samazinot kaulaudu mineralizāciju (Verbercmoes et al., 2003). Tādēḷ, lai labāk izprastu to lomu, 
osteoporotisko kaulaudu atjaunošanās mehānismos nepieciešami turpmāki pētījumi ar dažādu stroncija daudzumu biomateriālā.

Pētot Rīgas Tehniskās universitātes Rūdolfa Cimdiṇa Rīgas biomateriālu inovāciju un attīstības centra divfāžu kalcija fosfâta biokeramikas ietekmi uz kaulaudiem implantācijas vietas tuvumā (labajā augšstilbā), bija jānoskaidro, vai šim biomateriālam ir arī kaut kāda ietekme uz kaulaudiem attālinātos rajonos, piemēram, kreisajā augšstilbā. Mūsu pētījumā tika salīdzināti abu augšstilbu biomehāniskie parametri un minerālblīvums pēc biomateriāla implantācijas. Salīdzinot operētu un neoperētu augšstilba paraugu graujošo deformāciju, graujošo spriegumu, elastības moduli un minerālblīvumu, statistiski ticamas atšķirības netika atrastas $(\mathrm{p}>0,05)$. No tā var secināt, ka pētījumā izmantoto biomateriālu ietekme uz osteoporotisko kaulu biomehāniskiem parametriem un minerālblīvumu implantācijas vietas tuvumā (labajā augšstilbā) un attālinātā rajonā (kreisajā augšstilbā) ir vienāda, kas liecina par sistēmisku biomateriāla iedarbību uz osteoporotisko trušu kaulaudiem. 


\section{Secinājumi}

1. Osteoporotisko trušu paraugu graujošā deformācija pēc biomateriāla implantācijas ir statistiski ticami mazāka, salīdzinot ar placebo ķirurğijas grupu, kas liecina par kaulu uzlabotu spēju pretoties deformācijas spēkiem.

2. Neoperēta augšstilba un apakšžokḷa paraugu graujošais spriegums pēc biomateriāla implantācijas ir statistiski ticami lielāks, salīdzinot ar placebo ķirurgiijas grupu, kas liecina par kaulu izturības palielināšanu. Savukārt operēta augšstilba paraugu grupās statistiski ticamas atšķirības netika atrastas.

3. Operēta, neoperēta augšstilba un apakšžokḷa paraugu elastības modulis pēc biomateriāla implantācijas ir statistiski ticami lielāks, salīdzinot ar placebo ķirurg̣ijas grupu, kas liecina par kaulu stinguma īpašību palielināšanos.

4. Osteoporotisko trušu paraugu minerālblīvums pēc biomateriāla implantācijas ir statistiski ticami lielāks, salīdzinot ar placebo ķirurğijas grupu, kas liecina par sistēmisku biomateriālu iedarbību uz eksperimentālo dzīvnieku kauliem.

5. Salīdzinot operēta un neoperēta augšstilba paraugu biomehāniskos parametrus un minerālblīvumu grupām pēc biomateriālu implantācijas, statistiski ticamas atšķirīibas netika atrastas, kas liecina par vienādu biomateriālu iedarbību uz osteoporotiskiem kauliem, kas atrodas attālināti no implantācijas vietas.

6. Stronciju saturoši biomateriāli uzlabo kaulu biomehāniskās īpašības, salīdzinot ar pārējām osteoporotisku dzīvnvieku grupām. Savukārt netika atrastas statistiski ticamas kaulu minerālblīvuma atšķirības pēc biomateriāla implantācijas ar vai bez stroncija klātbūtnes.

7. Šḳērsgriezumā trabekulārā kaula laukums veselo trušu kaulu paraugiem bija statistiski ticami lielāks nekā osteoporotiskiem trušiem, kas ir eksperimentālo dzīvnieku grupu osteoporozes pierādījums. Savukārt līdzīgais trabekulārā kaula laukums visām osteoporotisko dzīvnieku grupām liecina par nemainīgu kaula apjomu pēc biomateriāla implantācijas. 


\section{Izmantotā literatūra}

1. Baier, M., Staudt, P., Klein, R., Sommer, U. et al. 2013. Strontium enhances osseointegration of calcium phosphate cement: a histomorphometric pilot study in ovariectomized rats. Journal of Orthopaedic Surgery and Research. $8,16$.

2. Baofeng, L., Zhi, Y., Bei, C., Guolin, M. et al. 2010. Characterization of a rabbit osteoporosis model induced by ovariectomy and glucocorticoid. Acta Orthopaedica. 81, 396-401.

3. Blanchard, R., David, C., Thomas, L., Hardiman, R., Clement, J. G., Cooper, D. C., Pivonka, P. 2019. Structural and Material Changes of Human Cortical Bone with Age: Lessons from the Melbourne Femur Research Collection. Encyclopedia of Biomedical Engineering. 246-264.

4. Boyle, W. J., Simonet, W. S., Lacey, D. L. 2003. Osteoclast differentiation and activation. Nature. 15(423(6937)), 337-342.

5. Calciolari, E., Donos, N., Mardas, N. 2017. Osteoporotic Animal Models of Bone Healing: Advantages and Pitfalls. J. Invest. Surg. 30, 342-350.

6. Castaneda, S., Calvo, E., Largo, R., Gonzalez-Gonzalez, R., de la Piedra, C., Diaz-Curiel, M., Herrero-Beaumont, G. 2008. Characterization of a new experimental model of osteoporosis in rabbits. J. Bone Miner. Metab. 26, 5359.

7. Charan, J, Kantharia, N. D. 2013. How to calculate sample size in animal studies? J. Pharmacol. Pharmacother. 4, 303-306.

8. Cosman, F., de Beur, S. J., LeBoff, M. S., Lewiecki, E. M., Tanner, B., Randall, S., Lindsay, R. 2014. Clinician's Guide to Prevention and Treatment of Osteoporosis. Osteoporos. Int. 25(10), 2359-2381.

9. Danciu, T. E. et al. 2003. Calcium regulates the PI3K-Akt pathway in stretched osteoblasts. FEBS Lett. 536, 193-197.

10. Dimitriou, R., Jones, E., McGonagle, D., Giannoudis, P. V. 2011. Bone regeneration: Current concepts and future directions. BMC Med. 9, 66-71.

11. Dorozhkin, S. V. 2007. Calcium orthophosphates. JMatS. 42, 1061-1995.

12. Ehret, C., Aid-Launais, R., Sagardoy, T., Siadous, R., Bareille, R., Rey, S., Pechev, S., Etienne, L., Kalisky, J., de Mones, E., Letourneur, D., Amadee Vilamitjana, J. 2017. Strontium-doped hydroxyapatite polysaccharide materials effect on ectopic bone formation. PLoS One. 12 (9), e0184663.

13. Endoskeleton of Rabbit (With Diagram). NotesOnZoology.com. Fig. 29.11 un 29.19. (http://www.notesonzoology.com/rabbit/endoskeleton/endoskele ton-of-rabbit-with-diagram-vertebrates-chordata-zoology/7690).

14. Evans, F. G. 1971. The Mechanical Properties of Bone. Charles and Thomath Publisher. 322. 
15. Föger-Samwald, U., Dovjak, P., Azizi-Semrad, U., Kerschan-Schindl, K., Pietschmann, P. 2020. Osteoporosis: Pathophysiology and therapeutic options. EXCLI J. 19, 1017-1037.

16. Grybauskas, S., Locs, J., Salma, I., Salms, G., Berzina-Cimdina, L. 2016. Volumetric analysis of implanted biphasic calcium phosphate/collagen composite by three-dimensional cone beam computed tomography head model superimposition. Journal of Cranio-Maxillofacial Surgery. 43(1), 167-174.

17. Grynpas, M.D., et al. 1996. Strontium increases vertebral bone volume in rats at a low dose that does not induce detectable mineralization defect. Bone. 18(3), 253-259.

18. Hao, J., Chou, J., Kuroda, S., Otsuka, M., Kasugai, S., Lang, N. P. 2015. Strontium hydroxyapatite in situ gel-forming system - a new approach for minimally invasive bone augmentation. Clin. Oral Implants Res. 26, 581585.

19. Henriksen, K., Byrjalsen, I., Andersen, J. R., Bihlet, A. R., Russo, L. A., Alexandersen, P. et al. 2016. A randomized, double-blind, multicenter, placebo-controlled study to evaluate the efficacy and safety of oral salmon calcitonin in the treatment of osteoporosis in postmenopausal women taking calcium and vitamin D. Bone. 91, 122-129.

20. Iaquinta, M. R., Mazzoni, E., Manfrini, M., D’Agostino, A., Trevisiol, L., Nocini, R., Trombelli, L., Barbanti-Brodano, G., Martini, F., Tognon, M. 2019. Innovative Biomaterials for Bone Regrowth. Int. J. Mol. Sci. 20(3), 618.

21. Ishikawa, K., Matsuya, S., Lin, X., Zhang, L., Yuasa, T., Miyamoto, Y. 2010. Fabrication of low crystalline B-type carbonate apatite block from low crystalline calcite block. J. Ceram. Soc. Jpn. 118, 341.

22. Jackman, T. M., Hussein, A. I., Adams, A. M., Makhnejia, K. K., Morgan, E. F. 2014. Endplate deflection is a defining feature of vertebral fracture and is associated with properties of the underlying trabecular bone. J. Orthop. Res. 32, 880-886.

23. Jensen, A. T., Jensen, S. S., Worsaae, N. 2016. Complications related to bone augmentation procedures of localized defects in the alveolar ridge. A retrospective clinical study. Oral Maxillofac Surg. 20(2), 115-122.

24. Jonville-Bera, A. P., Autret-Leca, E. 2011. Adverse drug reactions of strontium ranelate (Protelos(囚) in France. Presse Med. 40(10), 453-462.

25. Kalu, D. N. 1991. The ovariectomized rat model of postmenopausal bone loss. Bone Miner., 15, 175-191.

26. Kanis, J. A., Cooper, C., Rizzoli, R., Reginster, J. Y. 2019. Scientific Advisory Board of the European Society for Clinical and Economic Aspects of Osteoporosis (ESCEO), the Committees of Scientific Advisors and National Societies of the International Osteoporosis Foundation (IOF). European guidance for the diagnosis and management of osteoporosis in postmenopausal women. Osteoporos Int. 30, 3-44. 
27. Kiernan, J. A. 2008. Histological and histochemical methods: theory and practice. Scion Pub. 12-170.

28. Kim, D. G. 2014. Can dental cone beam computed tomography assess bone mineral density? J. Bone Metab. 21(2), 117-126.

29. Kimmel, D. B. 2001. Animal models for in vivo experimentation in osteoporosis research. In: Marcus R., Feldman D., Kelsey J. (Eds.) Osteoporosis. Academic Press. 2, 29-47.

30. Leite, F. R. M., Ramalho, L. T. de O. 2008. Bone regeneration after demineralized bone matrix and castor oil (Ricinus communis) polyurethane implantation. J. Appl. Oral Sci. 16(2), 122-126.

31.Lode, A., Heiss, C., Knapp, G., Thomas, J., Nies, B., Gelinsky, M., Schumacher, M. 2017. Strontium-Modified Premixed Calcium Phosphate Cements for the Therapy. Acta Biomater. 1, 30664-30665.

32. Ni, G. X., Lu, W. W., Chiu, K. Y., Li, Z. Y., Fong, D. Y. T., Luk, K. D. K. 2006. Strontium-containing hydroxyapatite (Sr-HA) bioactive cement for primary hip replacement: an in vivo study. Journal of biomedical materials research. Part B, Applied biomaterials. 77(2), 409-415.

33. Nkenke, E., Neukam, F. W. 2014. Autogenous bone harvesting and grafting in advanced jaw resorption: morbidity, resorption and implant survival. Eur. J. Oral Implantol. 7, 203-217.

34. Offermanns, V., Andersen, O. Z., Riede, G., Sillassen, M., Jeppesen, C. S., Almtoft, K. P., Talasz, H., Öhman-Mägi, C., Lethaus, B., Tolba, R., Kloss, F., Foss, M. 2018. Effect of strontium surface-functionalized implants on early and late osseointegration: A histological, spectrometric and tomographic evaluation. Acta Biomater. 69, 385-394.

35. Prodinger, P. M., Foehr, P., Bürklein, D., Bissinger, O., Pilge, H., Kreutzer, K., Eisenhart-Rothe, R., Tischer, T. 2018. Whole bone testing in small animals: systematic characterization of the mechanical properties of different rodent bones available for rat fracture models. Eur. J. Med. Res. 23, 8.

36. Ratner, B. D., Hoffman, A. S., Schoen, F. J., Lemons, J. E. 2013. Biomaterials Science: An Introduction to Materials in Medicine, 3rd ed. Elsevier.

37. Saint-Jean, S. J., Camire, C. L., Nevsten, P., Hansen, S., Ginebra, M. P. 2005. Study of the reactivity and in vitro bioactivity of Sr-substituted alpha-TCP cement. J. Mater. Sci. Mater. Med. 16, 993-1001.

38. Sakkas, A., Wilde, F., Heufelder, M., Winter, K., Schramm, A. 2017. Autogenous bone grafts in oral implantology-is it still a "gold standard"? A consecutive review of 279 patients with 456 clinical procedures. Int. J. Implant Dent. 3, 23. 
39. Salma, I., Petronis, S., Pilmane, M., Skagers, A., Zalite, V., Locs, J. 2015. Local recovery of Bone tissue in Osteoporotic Rabbit Hip after Implantation of HAP/TCP Bioceramic Granules. 27th European Conference on Biomaterials. 409.

40. Schlickewei, C. W., Laaff, G., Andresen, A., Klatte, T. O., Rueger, J. M., Ruesing, J., Epple, M., Lehmann, W. 2015. Bone augmentation using a new injectable bone graft substitute by combining calcium phosphate and bisphosphonate as composite: An animal model. J. Orthop. Surg. Res. 10, 116.

41. Slutskii, L., Vetra, J. 1996. Letter to the editor: Biocompatibility and reactogenicity of materials: a semantic and logical analysis of definitions of their practical significance. Cells and Materials. 6(1-3), 137-142.

42. Sözen, T., Özış1k, L., Başaran, N. C. 2017. An overview and management of osteoporosis. Eur. J. Rheumatol. 4(1), 46-56.

43. Sulaiman, S. B., Keong, T. K., Cheng, C. H., Saim, A. B., Idrus, R. B. H. 2013. Tricalcium phosphate/hydroxyapatite (TCP-HA) bone scaffold as potential candidate for the formation of tissue engineered bone. Indian $J$. Med. Res. 137(6), 1093-1101.

44. Thomsen, J. S., Ebbesen, E. N., Mosekilde, L. 2002. Zone-dependent changes in human vertebral trabecular bone: clinical implications. Bone. 30, 664-669.

45. Turner, A. S. 2001. Animal models of osteoporosis: necessity and limitations. Eur. Cell Mater. 1, 66-81.

46. Verberckmoes, S.C., De Broe, M.E., D’Haese, P.C. 2003. Dose-dependent effects of strontium on osteoblast function and mineralization. Kidney Int. 64(2), 534- 43.

47. Wanderman, N. R., Mallet, C., Giambini, H., Bao, N., Zhao, C., Kai-Nan, A., Freedman, B. A., Nassr, A. 2018. An Ovariectomy-Induced Rabbit Osteoporotic Model: A New Perspective. Asian Spine J. 12(1), 12-17.

48. Wang, W., Yeung, K. W. K. 2017. Bone grafts and biomaterials substitutes for bone defect repair: A review. Bioact. Mater. 2, 224-247.

49. Yamada, H. 1970. Strength of Biological Materials. The Williams and Wilkins Company. 297.

50. Yang, L. P., Dong, Y. P., Luo, W. P., Zhu, T., Li, Q. T., Zhang, L. J., Kong, J., Yuan, Z. W., Zhao, Q. 2018. Calbindin-D28K mediates 25(OH)D3/VDRregulated bone formation through MMP13 and DMP1. J. Cell Biochem. 119, 8035-8047.

51.Zarins, J., Pilmane, M., Sidhoma, E., Salma, I., Locs, J. 2017. Local and systemic morphofunctional response of osteoporotic rabbits bone defect following implantation of strontium doped biphasic ceramic granules. Solid State Phenomena. 267, 124-131. 


\section{Autora publikācijas un tēzes par pētījuma tēmu}

\section{Publikācijas starptautiski recenzējamos zinātniskos izdevumos}

1. Salms, G., Ananjevs, V., Kasyanovs, V., Skagers, A., Salma, I., Vetra, J., Zalite, V., Stipniece, L., Petronis, S. 2016. Change of Biomechanical Parameters in the Lower Jaws of Rabbits with Experimental Osteoporosis after Implantation of Calcium-Phosphate Bioceramic Material in the Greater Trochanter Region. Key Engineering Materials. 721, 224-228.

2. Ananjevs, V., Ananjeva, A., Vetra, J., Skagers, A., Salma, I., Locs, J., Kasyanov, V. 2018. Calcium Phosphate Bioceramic Material Local Influence on the Bone Biomechanical Properties at Rabbits with Experimental Osteoporosis. International Journal of Engineering \& Technology. 7, 496-497.

3. Ananjevs, V., Ananjeva, A., Vetra, J., Skagers, A., Salma, I., Neimane, L., Kasyanov, V. 2019. General influence of biphasic calcium phosphate on osteoporotic bone density. Proceedings of the Latvian Academy of sciences. Section B. 73(2), 185-188.

4. Ananjevs, V., Abolins, A., Locs, J., Salma, I., Skagers, A., Vetra, J., Kasyanov, V. 2020. The Histomorphometry of Rabbit Bone Tissue with Experimental Osteoporosis after Implantation of Biphasic Calcium Phosphate Materials. Key Engineering Materials. 850, 249-253.

\section{Publikācijas Latvijā recenzējamos zinātniskos izdevumos}

1. Anaņjevs, V., Skağers, A., Šalma, I., Šalms, G̣., Vētra, J., Vītiņš, V., Zālīte, V., Stīpniece, L., Kasjanovs, V. 2016. Osteoporotisku apakšžokḷa kaulu biomehānisko rādītāju izmaiņas pēc lokālas pastiprināšanas ar bifāziskajiem kalcija fosfātu biokeramikas materiāliem augšstilba trochanter majus rajonā: eksperimentāls pētījums. RSU zinātnisko rakstu krājums. 258-261. 


\section{Tēzes starptautiskās zinātniskās konferencēs}

1. Ананьев В., Ветра Я. Шалма И., Шалмс Г., Касьянов В., Лочс Я. Изменения биомеханических показателей в нижних челюстях кроликов с экспериментальным остеопорозом после локального использования кальций-фосфатного биокерамического материала в районе большого вертеля бедренной кости. Сборник трудов Национального конгресса с международным участием “Паринские чтения 2016” (Паринские чтения 2016, 5-6 мая 2016 г., Минск, Белоруссия), 20-23.

2. Šalms, G.., Anaṇjevs, V., Kasjanovs, V., Skaǵers, A., Šalma, I., Vētra, J., Zālīte, V., Stīpniece, L., Petronis, S. Change of Biomechanical Parameters in the Lower Jaws of Rabbits with Experimental Osteoporosis after Implantation of Calcium-Phosphate Bioceramic Material in the Greater Trochanter Region. BALTMATTRIB, Abstract (November 3-4, 2016, Riga, Latvia), 28.

3. Ananjevs, V., Vetra, J., Skagers, A., Salma, I., Locs, J., Kasyanov, V. Calcium phosphate bioceramic material local influence on the osteoporotic bone biomechanical properties (experimental research). 14th Joint Symposium of the Rostock University and Rīga Stradiňš University (24-26 May, 2018, Riga, Latvia).

4. Ananjevs, V., Vetra, J., Skagers, A., Salma, I., Locs, J., Kasyanov, V. Change of the Bone Biomechanical Properties at Rabbits with Experimental Osteoporosis after Implantation of Calcium Phosphate Bioceramic Material. 8th World Congress of Biomechanics (8-12 July, 2018, Dublinā, İrija).

5. Ananjevs, V., Locs, J., Abolins, A., Salma, I., Vetra, J., Skagers, A., Kasyanov, V. The histomorphometry of rabbits bone tissue with experimental osteoporosis after implantation of biphasic calcium phosphate materials. Materials Science and Applied Chemistry: Abstract (October 24, 2019, Riga, Latvia), 22. 


\section{Tēzes Latvijas zinātniskās konferencēs}

1. Ananjjevs, V., Vētra, J., Skaǵers, A., Kasjanovs, V., Šalma, I., Šalms, G̣., Ločs, J. Osteoporotisku trušu kaulu biomehānisko rādītāju izmaiņas pēc lokālas pastiprināšanas ar bifāziskajiem kalcija fosfātu biokeramikas materiāliem. Rīgas Stradiṇa universitāte. 2017. gada zinātniskā konference: Tēzes (Rīgā, 2017. gada 6. -7 . aprīīì), 45 .

2. Anaṇjevs, V., Vētra, J., Kasjanovs, V., Skag̉ers, A., Šalma, I., Neimane, L. Bifāziska kalcija fostāta biokeramikas materiāla vispārējā ietekme uz osteoporotisku kaulu minerālblīvumu: eksperimentāls pētījums. Rīgas Stradiṇa universitāte. 2018. gada zinātniskā konference: Tēzes (Rīgā, 2018. gada 22.-23. martā), 24.

3. Ananjevs, V., Ananjeva, A., Vetra, J., Skagers, A., Kasjanovs, V. Calcium Phosphate Bioceramic Materials General Influence on Osteoporotic Bone: Experimental Research. Rīgas Stradiña universitāte. 2019. gada starptautiskā konference - zināšanas praksei: Tēzes (R̄̄oā, 2019. gada 1.-3. aprīīi), 514 .

4. Ananjevs, V., Grisulonoks, A., Ananjeva, A., Abolins, A., Salma, I., Salms, G., Vetra, J., Kasjanovs, V., Skagers, A. Histopathology of Rabbits Jaws with Experimental Osteoporosis and Implantation of Biphasic Calcium Phosphates (BCP) in Trochanter Major. Rìgas Stradiṇa universitāte. 2019. gada strarptautiskā konference - zināšanas praksei: Tēzes (R̄̄gā, 2019. gada 1.-3. aprīlī), 578 . 


\section{Pateicības}

Ar dziḷu cieņu pateicība Dr. med., Dr. habil. med. profesoram Andrejam Skaǵeram un $\mathrm{Dr}$. med. docentei Ilzei Šalmai par atbalstu un padomiem mana promocijas darba tapšanā.

Ĺoti pateicos zinātniskā darba vadītājiem - Dr. habil. med. profesoram Jānim Vētram un Dr. habil. sc. ing. profesoram Vladimiram Kasjanovam par darba vadīšanu, atbalstu un lielu pacietību darba tapšanas laikā.

Pateicos Dr. med. asociētajam profesoram Arnim Āboliṇam par palīdzību kaulu paraugu morfologiskā pētîjuma veikšanā.

Paldies RSU Stomatologijas Institūta Rentgenologijas nodaḷas speciālistiem par lielo praktisko palīdzību kaulu paraugu datortomogrāfijas veikšanā. Īpaša pateicība $\mathrm{Dr}$.med. asociētajai profesorei Laurai Neimanei par padomiem.

Pateicos Rīgas Stradiņa universitātei par iespēju studēt doktorantūrā un papildināt savas zināšanas, par finansiālu atbalstu dalībai starptautiskās konferencēs.

Paldies Rīgas Tehniskās universitātes Rūdolfa Cimdina Rīgas biomateriālu inovāciju un attīstības centra speciālistiem par padomiem.

Paldies "Liepadent" zobārstniecības klīnikas vadītājam Armandam Ginteram par padomiem un palīdzību kaulu paraugu sagatavošanā biomehāniskai izpētei.

Vissirsnīgākais paldies un pateicība manai sievai Aleksandrai, dēlam Savēlijam un maniem vecākiem par sapratni, atbalstu un rūpēm. 